Article

\title{
Comparison of Chemical Compositions, Antioxidant, and Anti-Photoaging Activities of Paeonia suffruticosa Flowers at Different Flowering Stages
}

\author{
Jingyu He ${ }^{1}$, Yaqian Dong ${ }^{2}$, Xiaoyan Liu ${ }^{2}$, Yiling Wan ${ }^{2}$, Tanwei Gu ${ }^{2} \mathbb{D}$, Xuefeng Zhou ${ }^{3,4, *} \mathbb{C}$ and \\ Menghua Liu 2,*(D) \\ 1 Bioengineering Research Centre, Guangzhou Institute of Advanced Technology, Chinese Academy of \\ Sciences, Guangzhou 511458, China \\ 2 Guangdong Provincial Key Laboratory of New Drug Screening, School of Pharmaceutical Sciences, Southern \\ Medical University, Guangzhou 510515, China \\ 3 CAS Key Laboratory of Tropical Marine Bio-Resources and Ecology, South China Sea Institute of Oceanology, \\ Chinese Academy of Sciences, Guangzhou 510301, China \\ 4 Guangdong Key Laboratory of Marine Materia Medica, South China Sea Institute of Oceanology, Chinese \\ Academy of Sciences, Guangzhou 510301, China \\ * Correspondence: xfzhou@scsio.ac.cn (X.Z.); liumenghua@smu.edu.cn (M.L.); Tel.: +86-20-89023174 (X.Z.); \\ +86-20-6164-8597 (M.L.)
}

Received: 15 July 2019; Accepted: 20 August 2019; Published: 1 September 2019 updates

\begin{abstract}
Paeonia suffruticosa is an ornamental, edible, and medicinal plant. The ethanolic extracts of $P$. suffruticosa bud and flower were examined for their antioxidant, anti-photoaging, and phytochemical properties prior to chemometric analysis. The results showed that the bud ethanolic extract (BEE) and the flower (the early flowering stage) ethanolic extract (FEE) had better antioxidant activities, and significantly increased the activities of superoxide dismutase (SOD) and glutathione peroxidase (GSH-Px) and reduced the levels of tumor necrosis factor- $\alpha$ (TNF- $\alpha$ ) and interleukin-6 (IL-6) in the skin tissues. In total, 68 compounds, including 20 flavonoids, 15 phenolic derivatives, 12 terpenoids, 9 fatty acids, and 12 others were identified or tentatively identified by ultra-fast liquid chromatography quadrupole time-of-flight mass spectrometry (UFLC-Q-TOF-MS). Gallic acid, 1,2,3,4,6-O-pentagalloyl glucose, paeoniflorin, and oxypaeoniflorin were predominant compounds in the extracts. Taken together, $P$. suffruticosa flowers are a candidate for functional material in food and health related industries, and their optimal time to harvest is before the early flowering stage.
\end{abstract}

Keywords: Paeonia suffruticosa; flower; antioxidant activity; anti-photoaging activity; phytochemicals; chemometric analysis

\section{Introduction}

Ultraviolet-B (UVB) radiation is one of the most effective constituents of solar light, and has become the primary source of oxidative stress to humans. UVB generally impacts the basal layer of epidermal skin and causes premature skin photoaging, local and systemic immunosuppression, cutaneous inflammatory disorders, and photocarcinogenesis [1]. It is concluded that oxidative stress is a problem of skin cells and that endogenous and exogenous antioxidants could play an important role in decreasing it [2]. A large number of phytochemicals obtained from plants could reduce the harmful effects of oxidative stress and help to prevent the photoaging of skin [3,4]. Experimental and epidemiological studies indicated that the consumption of plant foods is related to lower incidence of age-related diseases [5]. Thus, there is increasing interest in the antioxidant properties of phytochemicals found in plant foods. 
Paeonia suffruticosa, belonging to Paeoniaceae, is mainly distributed in China, Japan, America, and Europe, and is an ornamental, edible, and medicinal plant in China and Japan [6,7]. Root bark of P. suffruticosa, named Cortex Moutan, is an important Chinese traditional medicine with the functions of lowering blood sugar, lowering blood pressure, anti-inflammatory, anti-bacterial, anti-tumor, and regulating the cardiovascular system [8]. P. suffruticosa flower as a characteristic natural resource that also has a long history of medicinal and edible use in China. Monoterpenoids, flavonoids, and essential oil have been found in P. suffruticosa flower $[6,9,10]$. The essential oils of $P$. suffruticosa flower buds possesses an inhibitory effect on common food-borne bacterial pathogens [6]. Moreover, P. suffruticosa flower as medicinal herb is used for the treatment of gynaecological diseases, and has experienced a growing number of applications in the food industry to produce cake, herbal tea, and drink, as well as in the cosmetic industry to produce facial masks and sunscreen creams. It is known that the chemical constituents that are responsible for the bioactivity are affected by the different flowering stages [11,12]. However, the characteristic phytochemicals and the composition change in the flowers are unclear and there is no principle to guide as to which flowering stage is suitable for harvesting when the flower is used in industry. The study on the relationship between phytochemicals and bioactivity during the flowering stages is less documented, which is a limitation to the development of products originated from the P. suffruticosa flower.

In this study, the antioxidant activities of the ethanolic extracts of $P$. suffruticosa flowers were evaluated using four different methods, including 2,2-diphenyl-1-picrylhydrazyl (DPPH) and hydroxyl radical scavenging activity, inhibition of $\beta$-carotene bleaching, and ferric reducing antioxidant power (FRAP) assays. The anti-photoaging activity of the ethanolic extracts of $P$. suffruticosa flowers was evaluated using a UVB-irradiated mouse model. The characteristic chemicals of the ethanolic extract of $P$. suffruticosa flowers were investigated prior to the correlation analysis between the multiple ingredients and their bioactivities.

\section{Materials and Methods}

\subsection{Plant Materials}

P. suffruticosa flowering buds were collected on 30 March 2016, and P. suffruticosa flowers at the early flowering stage were collected ten days later. P. suffruticosa flowers at the full flowering stage was collected on 20 April 2016, and then divided into petal and stamen (Figure 1). All of P. suffruticosa samples were collected in Luoyang, Henan province, China. All voucher specimens were stored at the Guangzhou Institute of Advanced Technology, Chinese Academy of Sciences, Guangdong, China.

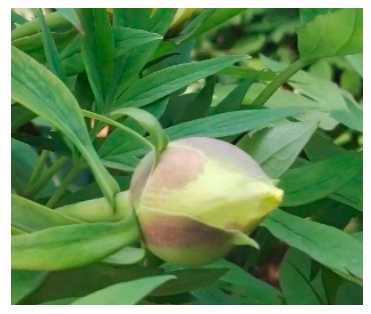

(A)

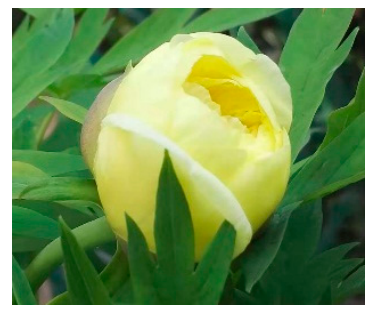

(B)

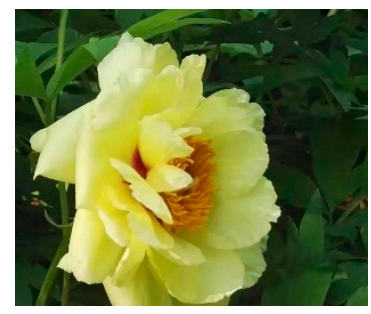

(C)

Figure 1. Pictures of Paeonia suffruticosa flowers at the different flowering stages. (A) P. suffruticosa flowering bud; (B) P. suffruticosa flower at the early flowering stage; (C) P. suffruticosa flower at the full flowering stage.

\subsection{Chemicals and Reagents}

Leucine, gallic acid, adenosine, tryptophan, and $p$-hydroxybenzoic acid were purchased from the National Institute for the Control of Pharmaceutical and Biological Products (Beijing, China). Morroniside, loganin, and geniposide were purchased from Chengdu Biopurify Phytochemicals Ltd. (Chengdu, 
China). Paeoniflorin, oxypaeoniflorin, benzoylpaeoniflorin, paeonol, 1,2,3,4,6-O-pentagalloyl glucose, luteolin, and apigenin were purchased from Chengdu Pufei De Biotech Co., Ltd. (Chengdu, China). Quercetin-3-O-glucoside and rhoifolin were purchased from Sigma-Aldrich (Shanghai, China). Hexadecanoic acid, 9-octadecenoic acid, octadecanoic acid, and 2,4,6-tris(2-pyridyl)-1,3,5-triazine were purchased from Shanghai Yuan Ye Biotechnology Co., Ltd. (Shanghai, China). 2,2-diphenyl1-picrylhydrazyl (DPPH), butylated hydroxytoluene (BHT), $\beta$-carotene, and vitamin C (VC) were purchased from Shanghai Ekear Bio-Tech Co., Ltd. (Shanghai, China). HPLC-grade acetonitrile and LC/MS grade methanol were purchased from Fisher Scientific (Fair Lawn, NJ, USA). Water was obtained from an ultrapure water system (Purelab Plus, Pall, Port Washington, NY, USA).

\subsection{Sample Preparation}

The dried and ground sample (100 g) was extracted with 95\% (v/v) ethanol (800 mL) in a KQ600DE ultrasonic bath (Kunshan, Jiangsu, China) for $30 \mathrm{~min}$ at room temperature. This extraction was repeated after filtration. The combined filtrate was evaporated under vacuum to yield the ethanolic extract. The dried ethanolic extract was weighed accurately and dissolved in $95 \%$ ethanol to obtain a series of solutions with different concentrations for the further study.

\subsection{Total Phenolic Content Assay}

Total phenolic content was determined using the described method [13]. Sample solution (1.0 mL) was mixed with the Folin-Ciocalteu reagent $(5.0 \mathrm{~mL} ; 0.1 \mathrm{mmol} / \mathrm{L})$ and allowed to incubate for $5 \mathrm{~min}$. A sodium carbonate solution $(4.0 \mathrm{~mL} ; 75 \mathrm{~g} / \mathrm{L})$ was added, and the mixture was vortexed and incubated at $25{ }^{\circ} \mathrm{C}$ for $30 \mathrm{~min}$ in darkness. A standard gallic acid solution was used and the absorbance was determined at $765 \mathrm{~nm}$ by spectrophotometer (UV-6100; Shanghai Metash Instrument Co., Ltd., Shanghai, China). Total phenolic content was expressed as $\mathrm{mg}$ gallic acid equivalents per gram of extract (mg GAE/g ext.). All measurements were performed in triplicate.

\subsection{Total Flavonoid Content Assay}

Total flavonoid content was measured using a previously reported method [13]. In this procedure, a mixture of an aliquot $(2.0 \mathrm{~mL})$ of sample solution, a $95 \%$ ethanol solution $(4.0 \mathrm{~mL})$, and sodium nitrite solution $(2.0 \mathrm{~mL} ; 50 \mathrm{~g} / \mathrm{L})$ was incubated at $25^{\circ} \mathrm{C}$ for $5 \mathrm{~min}$, and aluminium nitrate solution $(2.0 \mathrm{~mL}$; $100 \mathrm{~g} / \mathrm{L})$ was then added. After incubation at $25^{\circ} \mathrm{C}$ for $6 \mathrm{~min}$, sodium hydroxide solution $(5.0 \mathrm{~mL}$; $4 \mathrm{~g} / \mathrm{L}$ ) was added. Rutin was used to calculate the standard curve, and the absorbance was determined at $510 \mathrm{~nm}$ by spectrophotometer. Total flavonoid content was expressed as mg rutin equivalent per gram of extract (mg RE/g ext.). All measurements were performed in triplicate.

\subsection{Antioxidant Assay}

\subsubsection{DPPH Radical Scavenging Activity Assay}

DPPH radical scavenging activity was measured according to a previously reported method [14]. Briefly, sample solution $(1.0 \mathrm{~mL})$ was mixed with a freshly prepared methanol solution of DPPH $(1.0 \mathrm{~mL} ; 80 \mu \mathrm{g} / \mathrm{mL})$. The absorbance was measured at $517 \mathrm{~nm}$ spectrophotometrically after the mixture was incubated for $30 \mathrm{~min}$ at $25^{\circ} \mathrm{C}$. VC and BHT were used as two standard antioxidant compounds. All determinations were performed in triplicate. In control experiment, $95 \%$ ethanol $(2.0 \mathrm{~mL})$ was used. The radical scavenging capability of DPPH was calculated using the following equation: Scavenging effect $(\%)=\left(1-A_{\text {sample }} / A_{\text {control }}\right) \times 100$, where $A_{\text {sample }}$ and $A_{\text {control }}$ are the absorbance of the sample and the control, respectively.

\subsubsection{Hydroxyl Radical Scavenging Activity Assay}

The hydroxyl radical scavenging activity was determined according to a previously described method [13]. The hydroxyl radical was produced by the Fenton reaction between ferrous sulphate and 
hydrogen peroxide. Briefly, a sample solution $(2.0 \mathrm{~mL})$, a ferrous sulphate solution $(2.0 \mathrm{~mL} ; 5.0 \mathrm{mmol} / \mathrm{L})$, a salicylic acid solution $(2.0 \mathrm{~mL} ; 5.0 \mathrm{mmol} / \mathrm{L})$, and a hydrogen peroxide solution $(2.0 \mathrm{~mL} ; 5.0 \mathrm{mmol} / \mathrm{L})$ were added to the test tubes. The absorbance was measured spectrophotometrically at $510 \mathrm{~nm}$ after the mixture was incubated at $37^{\circ} \mathrm{C}$ for $1 \mathrm{~h}$. VC was used as the standard antioxidant compound. In control experiment, $95 \%$ ethanol $(2.0 \mathrm{~mL})$ was used. All determinations were performed in triplicate. The hydroxyl radical scavenging capability was calculated using the following equation: Scavenging effect $(\%)=\left[1-\left(A_{\text {sample }}-A_{\text {-hydrogen peroxide }}\right) / A_{\text {control }}\right] \times 100$, where $A_{\text {sample }}, A_{\text {-hydrogen peroxide, }}$, and $A_{\text {control }}$ are the absorbance of the sample, the sample without hydrogen peroxide, and the control, respectively.

\subsubsection{Ferric Reducing Antioxidant Power (FRAP) Assay}

In this study, FRAP assays were performed according to a previously described method [14]. The antioxidants could restore ferric tripyridyltriazine ( $\mathrm{Fe}^{3+}$-TPTZ) to blue $\mathrm{Fe}^{2+}$-TPTZ under acidic conditions. The FRAP solution was prepared by mixing acetate buffer $(300 \mathrm{mM}, \mathrm{pH} 3.6)$, TPTZ $(10 \mathrm{mM})$ and $\mathrm{FeCl}_{3}$ solution $(20 \mathrm{mM})$ in a ratio of 10:1:1 $(\mathrm{v} / \mathrm{v} / \mathrm{v})$. An aliquot $(0.15 \mathrm{~mL})$ of sample solution was mixed with the FRAP solution $(2.85 \mathrm{~mL})$ and incubated at $37^{\circ} \mathrm{C}$ for $30 \mathrm{~min}$. The total antioxidant activity of the samples could be evaluated by the absorbance of $\mathrm{Fe}^{2+}-\mathrm{TPTZ}$ at $593 \mathrm{~nm}$. All measurements were performed in triplicate. The results of the FRAP assay were reported in $\mathrm{mM} \mathrm{FeSO}_{4}$.

\subsubsection{Inhibition of $\beta$-Carotene Bleaching Assay}

Inhibitory ability of $\beta$-carotene bleaching was assessed according to a previously described method [14]. Briefly, a solution of $\beta$-carotene was prepared by dissolving $2 \mathrm{mg}$ in chloroform $(10 \mathrm{~mL})$. Two millilitres of this solution was pipetted into a round-bottom flask. After the chloroform was removed at $40{ }^{\circ} \mathrm{C}$ under vacuum, linoleic acid ( $40 \mathrm{mg}$ ), Tween- 80 emulsifier $(400 \mathrm{mg})$, and distilled water $(100 \mathrm{~mL})$ were added to the flask with vigorous shaking. An aliquot $(4.8 \mathrm{~mL})$ of this emulsion was transferred to different test tubes containing the sample solution $(0.2 \mathrm{~mL})$. A $4.8 \mathrm{~mL}$ portion of the emulsion combined with $95 \%$ ethanol $(0.2 \mathrm{~mL})$ was used as a control. The tubes were shaken and incubated at $50{ }^{\circ} \mathrm{C}$ in a water bath. As soon as the emulsion was added to each tube, the absorbance was measured at $470 \mathrm{~nm}$ at $0 \mathrm{~min}$ and at 15 -min intervals over a $120 \mathrm{~min}$ period. All measurements were performed in triplicate. The $\beta$-carotene bleaching inhibition was calculated using the following equation: Bleaching inhibition $(\%)=\left[1-\left(A_{\text {sample }-0}-A_{\text {sample- } t}\right) /\left(A_{\text {control- } 0}-A_{\text {control- } t}\right)\right] \times 100$, where $A_{\text {sample }-0}$ and $A_{\text {control- } 0}$ are the initial absorbance $(\mathrm{t}=0 \mathrm{~min})$ of the sample and the control, respectively; $A_{\text {sample- } t}$ and $A_{\text {control- } t}$ are the absorbance $(\mathrm{t}=15,30,45,60,75,90,105$, and $120 \mathrm{~min})$ of the sample and the control, respectively.

\subsection{Animal Treatment and UV Irradiation}

Kunming mice (body weights of 18-20 g) were purchased from the Experimental Animal Center of Southern Medical University (Guangzhou, China). Mice were fed on standard laboratory diet and water at libitum, and kept in $12 \mathrm{~h}$ dark/light cycle room at $21 \pm 3^{\circ} \mathrm{C}$ with a relative humidity of $55 \% \pm 10 \%$ for one week prior to the ultraviolet treatment. Animal experiments and all procedures were approved by the Animal Care and Use Committee of Southern Medical University (Guangzhou, China). Mice were randomly divided into 7 groups $(n=6)$, control group (no irradiation), model group (irradiated group with no treatment), model + emulsifier (ME) group (irradiated group treated with emulsifier containing stearic acid $10.0 \mathrm{~g}$, glycerin monostearate $3.0 \mathrm{~g}$, liquid paraffin $5.0 \mathrm{~g}$, vaseline $1.0 \mathrm{~g}$, lanolin $4.0 \mathrm{~g}$, triethanolamine $1.0 \mathrm{~g}$, and distilled water $50 \mathrm{~mL}$ ), bud ethanolic extract (BEE) group (irradiated group treated with 2.0\% (w/w) BEE in emulsifier), flower ethanolic extract (FEE) group (irradiated group treated with 2.0\% (w/w) FEE in emulsifier), petal ethanolic extract (PEE) group (irradiated group treated with 2.0\% (w/w) PEE in emulsifier), stamen ethanolic extract (SEE) group (irradiated group treated with $2.0 \%(w / w)$ SEE in emulsifier). The shaved dorsal skin of the mice was exposed to $120 \mathrm{~mJ} / \mathrm{cm}$ UVB radiations (emission peak $306 \mathrm{~nm}$; Sankyo Denki Co., Tokyo, Japan) for $20 \mathrm{~min}$, thrice a week. The preparations $(0.2 \mathrm{~g})$ were topically administered daily to the back of 
the mouse skin. Mice were anaesthetized and their dorsal skin tissues were collected at the end of experiment (4 weeks). Dorsal skin tissues were washed with physiological saline $(0.9 \% \mathrm{NaCl})$ and stored at $-80{ }^{\circ} \mathrm{C}$ until analyses were performed. Half of dorsal skin tissue was used for histological analysis, and the other half was used for biochemical analysis.

\subsection{Histological Analysis}

Dorsal mouse skin samples were fixed overnight with $4 \%$ paraformaldehyde in phosphate buffered saline (PBS) at $4{ }^{\circ} \mathrm{C}$ and then embedded in paraffin. Paraffin sections $(4 \mu \mathrm{m})$ were mounted on silane-coated slides and stained with Hematoxylin\&Eosin (H\&E) using H\&E staining kit (Sangon Biotech (Shanghai) Co., Ltd., Shanghai, China). The sections were examined, and images were recorded using a microscope and Image-Pro Express 5.1.1.14 Pathology Image Analysis System (Olympus Corporation, Tokyo, Japan) at 400× magnifications. The epidermal thickness was measured at 8 random sites randomly selected locations per slide using the image analysis program.

\subsection{Biochemical Analysis}

The dorsal skin tissues were homogenized in a glass homogenizer with a buffer containing $1.15 \%$ $\mathrm{KCl}$ in a 1:10 $(w / v)$ whole homogenate. The homogenates used for the biochemical analysis were obtained by centrifugation at $12,000 \times g$ for $30 \mathrm{~min}$. Protein levels in skin homogenates were measured using the Pierce BCA protein assay kit (Beyotime Biotechnology, Shanghai, China). Concentrations of superoxide dismutase (SOD), glutathione peroxidase (GSH-Px), tumor necrosis factor- $\alpha$ (TNF- $\alpha$ ), and interleukin-6 (IL-6) in dorsal skin tissues were determined using mouse-specific enzyme-linked immunosorbent assay (ELISA) kits (NeoBioscience, Shenzhen, China). Analysis was performed according to the manufacturer's instruction.

\subsection{UFLC-DAD-Q-TOF-MS Analysis}

\subsubsection{System and Conditions}

Ultra-fast liquid chromatography (UFLC) analysis was performed on a Shimadzu UFLC XR system (Shimadzu Corp., Kyoto, Japan) with an Agilent Eclipse Plus $C_{18}$ column (2.1 i.d. $\times 100$ mm, $1.8 \mu \mathrm{m}$, Agilent Technologies, CA, USA). The mobile phases were composed of methanol (A) and water with $0.1 \%$ formic acid (B) using a linear gradient elution of $5-100 \%$ A within $30 \mathrm{~min}$ at $0.3 \mathrm{~mL} / \mathrm{min}$. The injection volume was $5 \mu \mathrm{L}$, and the column temperature was set at $25^{\circ} \mathrm{C}$. The identification experiment was performed using AB SCIEX Triple TOF 5600 plus mass spectrometer system (AB SCIEX, Foster City, CA, USA). The system was operated using the Analyst TF 1.6 software (AB SCIEX, Foster City, CA, USA). The parameters of the MS detector were as follows: Ion source gas 155 psi; ion source gas 255 psi; curtain gas 30 psi; source temperature $550{ }^{\circ} \mathrm{C}$; ion spray voltage floating $4500 \mathrm{~V}$; collision energy $35 \mathrm{eV}$; collision energy spread $15 \mathrm{eV}$; and declustering potential $80 \mathrm{eV}$. Spectra were acquired in a scan range from $m / z 100-1500$. Both positive and negative ion modes were used for compounds ionization. Nitrogen was used as the nebulizer and auxiliary gas.

\subsubsection{Establishment of Tentative Peak Assignment}

The UFLC-Q-TOF-MS data of samples were extracted and analysed using the PeakView software (AB SCIEX, Foster City, CA, USA), mainly with the XIC manager tool, which provided the quasi-molecular weights, mass errors, and isotope pattern fits. The predicted formula with errors less than \pm 5 ppm was searched against the compounds reported in the genus Paeonia to obtain the tentative identification. The identification of the compounds within the samples was further confirmed by determining the possible elemental compositions of the fragment ions and the proposed fragmentation pathways using their MS spectrum. 


\subsection{HPLC-DAD Analysis}

High performance liquid chromatography (HPLC) analysis was performed on an Agilent (CA, USA) 1290 UPLC-DAD system with a reverse-phase Agilent EC- $\mathrm{C}_{18}$ column $(3.0$ i.d. $\times 100 \mathrm{~mm}, 2.7 \mu \mathrm{m}$, Agilent Technologies, CA, USA). A gradient elution mobile phase system composed of $0.5 \%$ formic acid solution (A) and acetonitrile (B) was applied as follows: 0-3 $\mathrm{min}, 5-8 \% \mathrm{~B} ; 3-4 \mathrm{~min}, 8-13 \% \mathrm{~B}$; 4-13 min, 13-14\% B; 13-14 min, 14-20\% B; 14-29 min, 20-30\% B; 29-30 min, 30-50\% B; 30-33min, $50-95 \% \mathrm{~B}$. The mobile phase flow rate was $0.3 \mathrm{~mL} / \mathrm{min}$, and the column temperature was maintained at $30{ }^{\circ} \mathrm{C}$. The injection volume was $5 \mu \mathrm{L}$ and the UV wavelength was set at $254 \mathrm{~nm}$.

The developed method was validated by linear range, limit of detection (LOD), limit of quantitation (LOQ), precision, and recovery according to the previous report [14].

\subsection{Statistical Analysis}

The results were expressed as the mean \pm standard deviation (SD) of each experiment. The data obtained were analysed using a one-way analysis of variance (ANOVA) followed by Tukey's multiple comparison test. A $p$ value $<0.05$ was considered to be significant. Pearson's correlation analysis was used to characterize the correlation between the phytochemicals and the bioactivities. One-way ANOVA and Pearson's correlation analysis were performed using the software IBM SPSS Statistics (version 19.0).

\section{Results and Discussion}

\subsection{Total Phenolic and Flavonoid Contents}

The extract yields of bud, flower, petal, and stamen of P. suffruticosa had obvious differences (Table 1). Total phenolic contents in the BEE, FEE, PEE, and SEE were determined. BEE had the highest total phenolic content $(191.80 \pm 3.44 \mathrm{mg}$ GAE/g ext.), followed by FEE (113.84 $\pm 0.84 \mathrm{mg} \mathrm{GAE} / \mathrm{g}$ ext.), SEE (77.25 $\pm 0.58 \mathrm{mg}$ GAE/g ext.) and PEE (51.66 $\pm 0.34 \mathrm{mg} \mathrm{GAE} / \mathrm{g}$ ext.). Unexpectedly, FEE had the highest total flavonoid content ( $49.87 \pm 0.82 \mathrm{mg} \mathrm{RE} / \mathrm{g}$ ext.), followed by BEE (30.60 $\pm 0.94 \mathrm{mg} \mathrm{RE} / \mathrm{g}$ ext.), PEE (12.98 $\pm 0.78 \mathrm{mg}$ RE/g ext.) and SEE ( $8.86 \pm 0.98 \mathrm{mg}$ RE/g ext.). Total phenolic content in the flowers had a trend of gradual decrease during the flowering stage of $P$. suffruticosa. In the other hand, there might be a maximum content of flavonoids in the flowering stage.

Table 1. Extraction yields, total phenolic, and total flavonoid contents, and antioxidant activities $\left(\mathrm{IC}_{50}\right.$ values) of Paeonia suffruticosa flowers.

\begin{tabular}{|c|c|c|c|c|c|c|}
\hline \multirow{2}{*}{ Items } & \multirow{2}{*}{ VC } & \multirow{2}{*}{ BHT } & \multicolumn{4}{|c|}{ Samples } \\
\hline & & & BEE & FEE & PEE & SEE \\
\hline Extraction yields (\%) & - & - & $35.46 \pm 3.12$ & $50.76 \pm 1.95$ & $42.72 \pm 2.48$ & $25.77 \pm 4.54$ \\
\hline Total phenolic content (mg GAE/g ext.) & - & - & $191.80 \pm 3.44$ & $113.84 \pm 0.84$ & $51.66 \pm 0.34$ & $77.25 \pm 0.58$ \\
\hline Total flavonoid content (mg RE/g ext.) & - & - & $30.60 \pm 0.94$ & $49.87 \pm 0.82$ & $12.98 \pm 0.78$ & $8.86 \pm 0.98$ \\
\hline DPPH radical scavenging activity $(\mu \mathrm{g} / \mathrm{mL})$ & $6.16 \pm 0.46$ & $64.49 \pm 4.68$ & $34.44 \pm 1.35$ & $14.83 \pm 2.03$ & $64.00 \pm 5.60$ & $42.70 \pm 0.79$ \\
\hline Hydroxyl radical scavenging activity $(\mathrm{mg} / \mathrm{mL})$ & $0.61 \pm 0.02$ & - & $1.57 \pm 0.04$ & $1.79 \pm 0.02$ & $2.57 \pm 0.06$ & $2.10 \pm 0.004$ \\
\hline
\end{tabular}

VC: vitamin C; BHT: butylated hydroxytoluene; BEE: bud ethanolic extract; FEE: flower ethanolic extract; PEE: petal ethanolic extract; SEE: stamen ethanolic extract. Data were expressed as mean $\pm \operatorname{SD}(n=3)$.

\subsection{Antioxidant Activity In Vitro}

The antioxidant capabilities of BEE, FEE, PEE, and SEE were tested by the DPPH and hydroxyl radical scavenging, FRAP, and inhibition of $\beta$-carotene bleaching assays (Figure 2). The FEE had stronger DPPH radical scavenging activity than the other extracts and BHT below $50 \mu \mathrm{g} / \mathrm{mL}$, while it was obviously weaker than that of VC at concentration 10-200 $\mu \mathrm{g} / \mathrm{mL}$. The BEE and SEE also had stronger activity than BHT. On the basic of $\mathrm{IC}_{50}$ values, antioxidant activity is defined as the concentration of antioxidant required for $50 \%$ scavenging of the radicals (Table 1 ). The $\mathrm{IC}_{50}$ value of FEE for scavenging DPPH was $14.83 \pm 2.03 \mu \mathrm{g} / \mathrm{mL}$, which was lower than that of BEE $(34.44 \pm 1.35 \mu \mathrm{g} / \mathrm{mL})$, 
PEE $(64.00 \pm 5.60 \mu \mathrm{g} / \mathrm{mL})$, and SEE $(42.70 \pm 0.79 \mu \mathrm{g} / \mathrm{mL})$. A lower $\mathrm{IC}_{50}$ value suggested that antioxidant activity was better in the four extracts. Unexpectedly, the $\mathrm{IC}_{50}$ value of $\mathrm{BEE}$ was $1.57 \pm 0.04 \mathrm{mg} / \mathrm{mL}$, which was lower than that of FEE $(1.79 \pm 0.02 \mathrm{mg} / \mathrm{mL})$, PEE $(2.57 \pm 0.06 \mathrm{mg} / \mathrm{mL})$, and SEE $(2.10 \pm$ $0.004 \mathrm{mg} / \mathrm{mL}$ ). The BEE had strongest hydroxyl radical scavenging activity than the other extracts, but was weaker than VC. In the FRAP assay, FEE had the strongest activity, followed by BEE, PEE, and SEE. Moreover, FEE had similar activity to BHT, but was much stronger than VC. The activity of BEE in the inhibition of the $\beta$-carotene bleaching assay was a little weaker than that of BHT $(100 \mu \mathrm{g} / \mathrm{mL})$ over $120 \mathrm{~min}$, but had stronger and longer lasting inhibitory activity than that of other extracts at $100 \mu \mathrm{g} / \mathrm{mL}$. Based on the results of the antioxidant evaluation, the antioxidant activities of BEE and FEE were noticeable. BEE had a greater effect on hydroxyl radical scavenging and inhibition of the $\beta$-carotene bleaching, whereas FEE had a greater effect on DPPH radical scavenging and FRAP. These results indicated that there was a correlation between bioactivity and the flowers at the different harvest time, due to the change of chemical compositions.

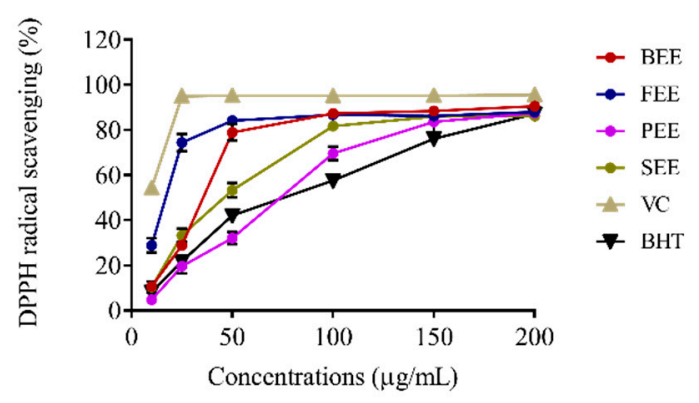

(A)

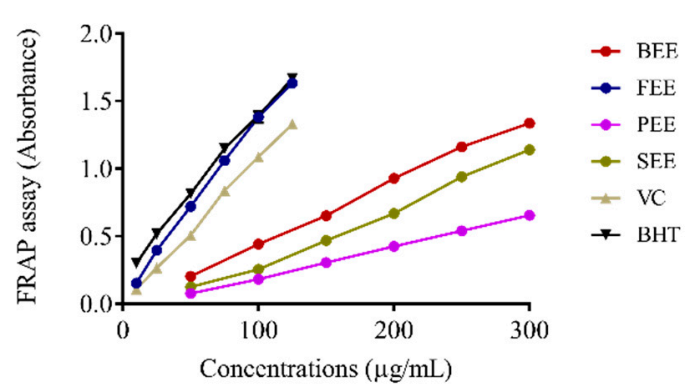

(C)

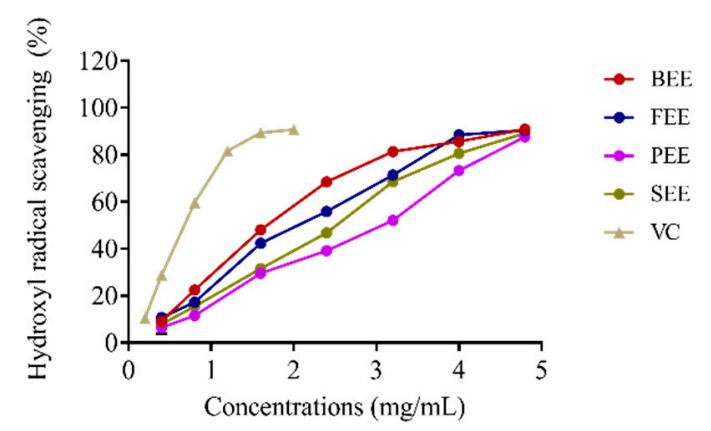

(B)

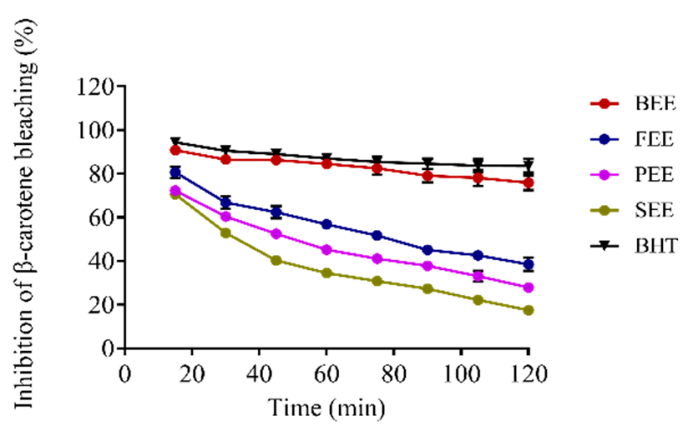

(D)

Figure 2. In vitro antioxidant effects of ethanolic extract of Paeonia suffruticosa flowers. Effects of ethanolic extract of P. suffruticosa flowers on DPPH scavenging (A), hydroxyl radical scavenging (B), FRAP assay $(\mathbf{C})$, and inhibition of $\beta$-carotene bleaching $(\mathbf{D})$. Data were expressed as mean $\pm \operatorname{SD}(n=3)$. VC: vitamin C; BHT: butylated hydroxytoluene; BEE: bud ethanolic extract; FEE: flower ethanolic extract; PEE: petal ethanolic extract; SEE: stamen ethanolic extract.

\subsection{Effects on the Morphology in Mouse Skin}

Skin that is exposed excessively to UVB irradiation is easily damaged. UVB irradiation led to excessive damage to the morphology and integrity of the mouse skin. It is reported that UVB radiation on the skin induces a variety of responses in the epidermis, including keratinocyte proliferation that leads to epidermal hyperplasia and thickening [15]. In this study, the change incurred on the mouse skin was assessed after UVB irradiation. The epidermal thickness of the ME group significantly increased 
by 1.14 fold when compared to that of the control group. In the case of the extract treatment groups, the epidermal thickness of BEE, FEE, PEE, and SEE groups significantly decreased $(p<0.001)$ to $70.62 \%$, $74.62 \%, 88.13 \%$, and $90.74 \%$, respectively, when compared to that of the ME group (Figure $3 \mathrm{H}$ ). Topical treatment with the four extracts had the effect of inhibiting the epidermal thickening, and of which BEE could best prevent UVB-induced damage to the skin. A lot of studies have reported natural products are the important resources of antioxidants $[16,17]$. Phenols and flavonoids, the main constituents in flowers, were considered as antioxidants and UV absorbing secondary metabolites [18,19]. It has also been reported that flavonoids help to prevent the skin photoaging by regulating pro-inflammatory cytokines [20,21]. Interestingly, abundant phenols and flavonoids were found in the BEE and FEE, respectively. Phenols and flavonoids in the BEE and FEE appear to be useful against the chronic effects of UV light. More studies on antioxidant and anti-inflammatory activities of the four extracts were performed in the next experiments.
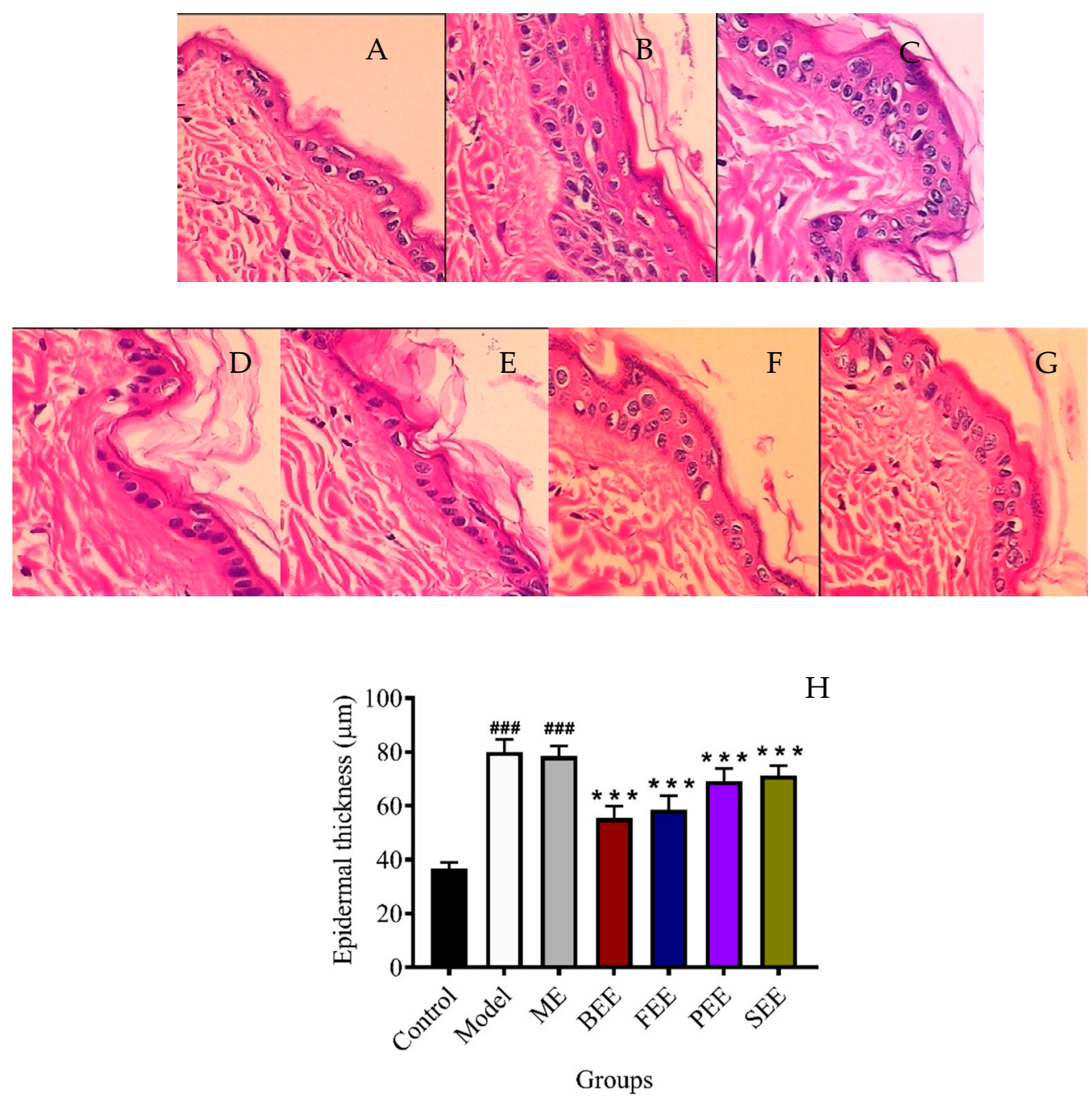

Figure 3. Effects of ethanolic extract of Paeonia suffruticosa flowers on UVB-induced epidermal thickening in the mice. Representative images of histological observation by H\&E staining of mouse dorsal skin (400×). (A) control group: no irradiation; (B) model group: irradiated group with no treatment; (C) model + emulsifier (ME) group: irradiated group treated with emulsifier; (D) bud ethanolic extract (BEE) group: irradiated group treated with 2.0\% (w/w) BEE in emulsifier; (E) flower ethanolic extract (FEE) group: irradiated group treated with 2.0\% (w/w) FEE in emulsifier; (F) petal ethanolic extract (PEE) group: irradiated group treated with $2.0 \%(w / w)$ PEE in emulsifier; (G) stamen ethanolic extract (SEE) group: irradiated group treated with $2.0 \%(w / w)$ SEE in emulsifier. $(\mathbf{H})$ Epidermal thickness. Data were expressed as mean $\pm \mathrm{SD}(n=6)$. ${ }^{* * *} p<0.001$ versus ME group; ${ }^{\# \# \# ~} p<0.001$ versus control group. 


\subsection{Effects on the Activities of SOD and GSH-Px in Mouse Skin}

The activities of endogenous antioxidants in the skin tissues were further investigated (Figure 4A,B). The activity of SOD in the model group and model + emulsifier groups was significantly decreased when compared with the control group. Using a UVB-irradiated mouse model, topical treatment with BEE and FEE could significantly increase $(p<0.05)$ the activity of SOD, but topical treatment with PEE and SEE had no significant effect on the activity of SOD. The activity of GSH-Px in the skin tissues was significantly decreased when the mice were treated with UVB irradiation. Topical treatment with BEE $(p<0.001)$, FEE $(p<0.001)$, PEE $(p<0.001)$, and SEE $(p<0.05)$ significantly increased the activity of GSH-Px in the skin of UVB irradiated mice.

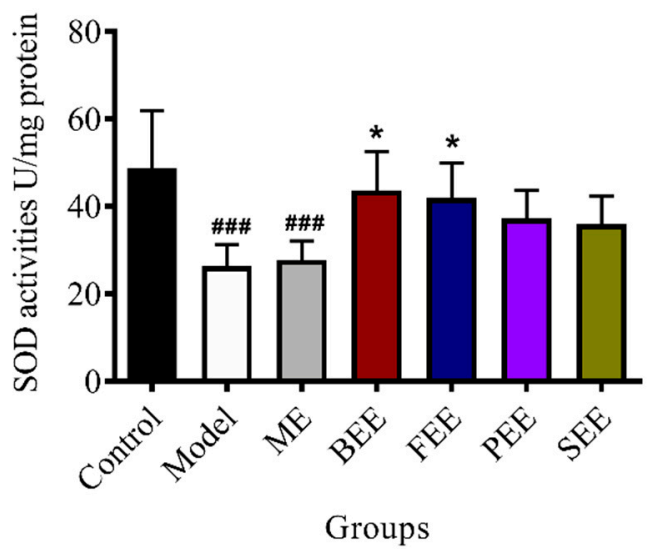

(A)

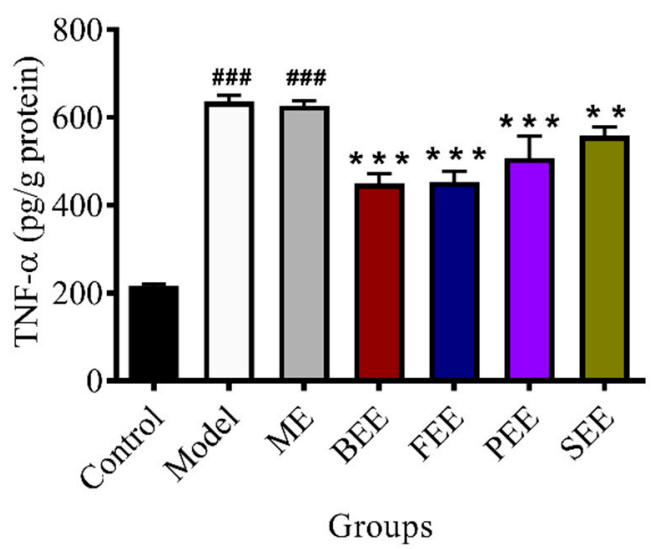

(C)

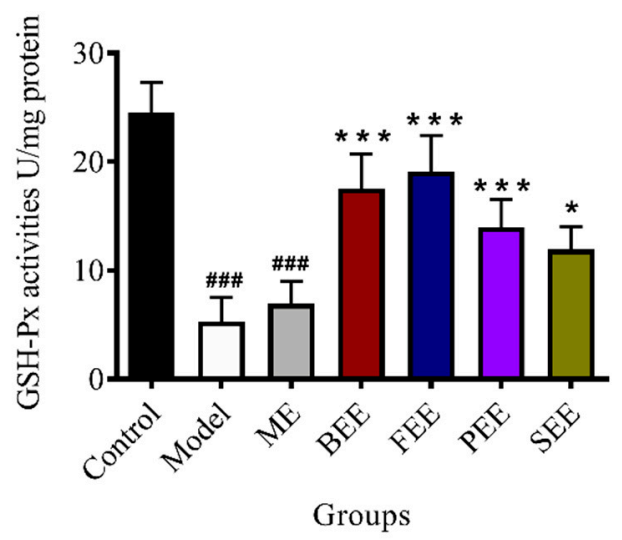

(B)

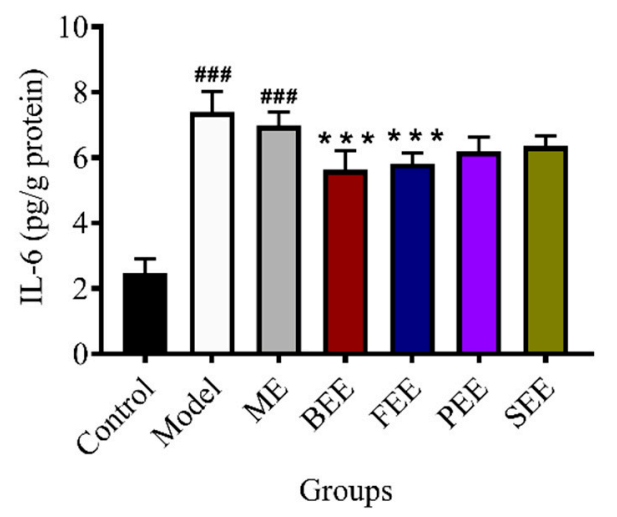

(D)

Figure 4. Effects of ethanolic extracts of Paeonia suffruticosa flowers on the activities of antioxidant enzymes and the concentrations of pro-inflammatory cytokines in UVB-irradiated mouse skin. Concentrations of SOD (A), GSH-Px (B), TNF- $\alpha$ (C), and IL-6 (D) in dorsal skin tissues were determined using mouse-specific enzyme-linked immunosorbent assay (ELISA) kits. Control group: no irradiation; Model group: irradiated group with no treatment; Model + emulsifier (ME) group: irradiated group treated with emulsifier; Bud ethanolic extract (BEE) group: irradiated group treated with $2.0 \%(w / w)$ BEE in emulsifier; Flower ethanolic extract (FEE) group: irradiated group treated with $2.0 \%(w / w)$ FEE in emulsifier; Petal ethanolic extract (PEE) group: irradiated group treated with $2.0 \%(w / w)$ PEE in emulsifier; Stamen ethanolic extract (SEE) group: irradiated group treated with $2.0 \%(w / w)$ SEE in emulsifier. Data were expressed as mean $\pm \operatorname{SD}(n=6) .{ }^{*} p<0.05,{ }^{* *} p<0.01$, and ${ }^{* * *} p<0.001$ versus ME group; ${ }^{\# \#} p<0.001$ versus control group.

UVB irradiated skin depletes antioxidant defensive capabilities [5]. ROS plays a significant role in UVB-induced skin carcinogenesis. In the body, endogenous antioxidants offset UV-induced oxidative 
stress by the neutralization of the ROS prior to oxidative changes occuring in the tissues [22]. SOD could alternately catalyze the dismutation of the superoxide radical into either ordinary molecular oxygen or hydrogen peroxide, and thereby is an important antioxidant defense [23]. GSH, a free radical-scavenger and a cofactor for protective enzymes, plays a pivotal role in protecting cells from oxidative damage [24]. Normally, these enzymes are able to scavenge the ROS efficiently, and consequently protect skin from damage. However, excessive and chronic exposure to UVB radiation can overwhelm the cutaneous antioxidant capacity leading to oxidative damage, resulting in skin photoaging [25]. BEE and FEE with excellent antioxidant capability could significantly increase the activities of SOD and GSH-Px in the damaged skin, which was responsible for inhibiting the epidermal thickening, consequently ameliorating the skin's pathological symptom.

\subsection{Effects on the Leveles of TNF- $\alpha$ and IL-6 in Mouse Skin}

As Figure 4C,D shows, inflammatory cytokines (TNF- $\alpha$ and IL-6) in the UVB irradiated group were significantly increased when compared with the control group. Topical treatment with BEE $(p<0.001)$, FEE $(p<0.001)$, PEE $(p<0.001)$, and SEE $(p<0.01)$ significantly decreased the content of TNF- $\alpha$ in the skin tissues of UVB irradiated mice. BEE and FEE could significantly decrease the content of IL-6 in the skin tissues of UVB irradiated mice. Contrarily, no significant effect on the contents of IL-6 was found in PEE and SEE treated groups.

Inflammation response that causes erythema, edema, and an influx of inflammatory cells, is one of the most obvious results of UVB radiation. Epidermal keratinocytes strongly contribute to cutaneous inflammation via their release of pro-inflammatory cytokines [26]. Pro-inflammatory cytokines, such as TNF- $\alpha$ and IL-6, play crucial roles in inflammatory development and are considered to be indicators of the degree of inflammation [27]. Moreover, pro-inflammatory cytokines stimulate the epidermal keratinocytes and dermal fibroblasts, and degrade dermal collagen and elastic fibers, consequently causing the epidermal thickening and the formation of wrinkles [4]. Accordingly, the inhibition of pro-inflammatory cytokines secretion induced by UVB irradiation is important to protect skin from photo-damage. BEE and FEE could significantly decrease the levels of TNF- $\alpha$ and IL-6 in damaged skin and thereby partly compensate for the inflammation induced by UVB radiation. As a result, the anti-inflammatory capability of BEE and FEE was responsible for ameliorating the skin's pathological symptom. These results suggested that the BEE and FEE, with more excellent antioxidant and anti-inflammatory capabilities, had a greater effect on the prevention of skin photoaging. Their molecular mechanism of anti-photoaging is still unclear and is, thus, required in future study.

\subsection{Chemical Compositions of Ethanolic Extracts of P. suffruticosa Flowers}

Compounds at the different flowering stages of $P$. suffruticosa were identified by UPLC-Q-TOF-MS/MS method through comparison retention time (Rt), accurate molecular weight (MW), and fragmentography with the reference standards. When no standards were unavailable, compounds were tentatively identified by the accurate molecular weight and fragmentation pathway, which had been carried out on the same kind of compounds or literature report. As shown in Table 2, a total of 68 compounds, including 12 monoterpenoids, 20 flavonoids, 15 phenols and their derivatives, 9 fatty acids, and 12 others, were identified or tentatively identified in this study. 
Table 2. The compounds identified in the ethanolic extracts of Paeonia suffruticosa flowers by UFLC-Q-TOF-MS.

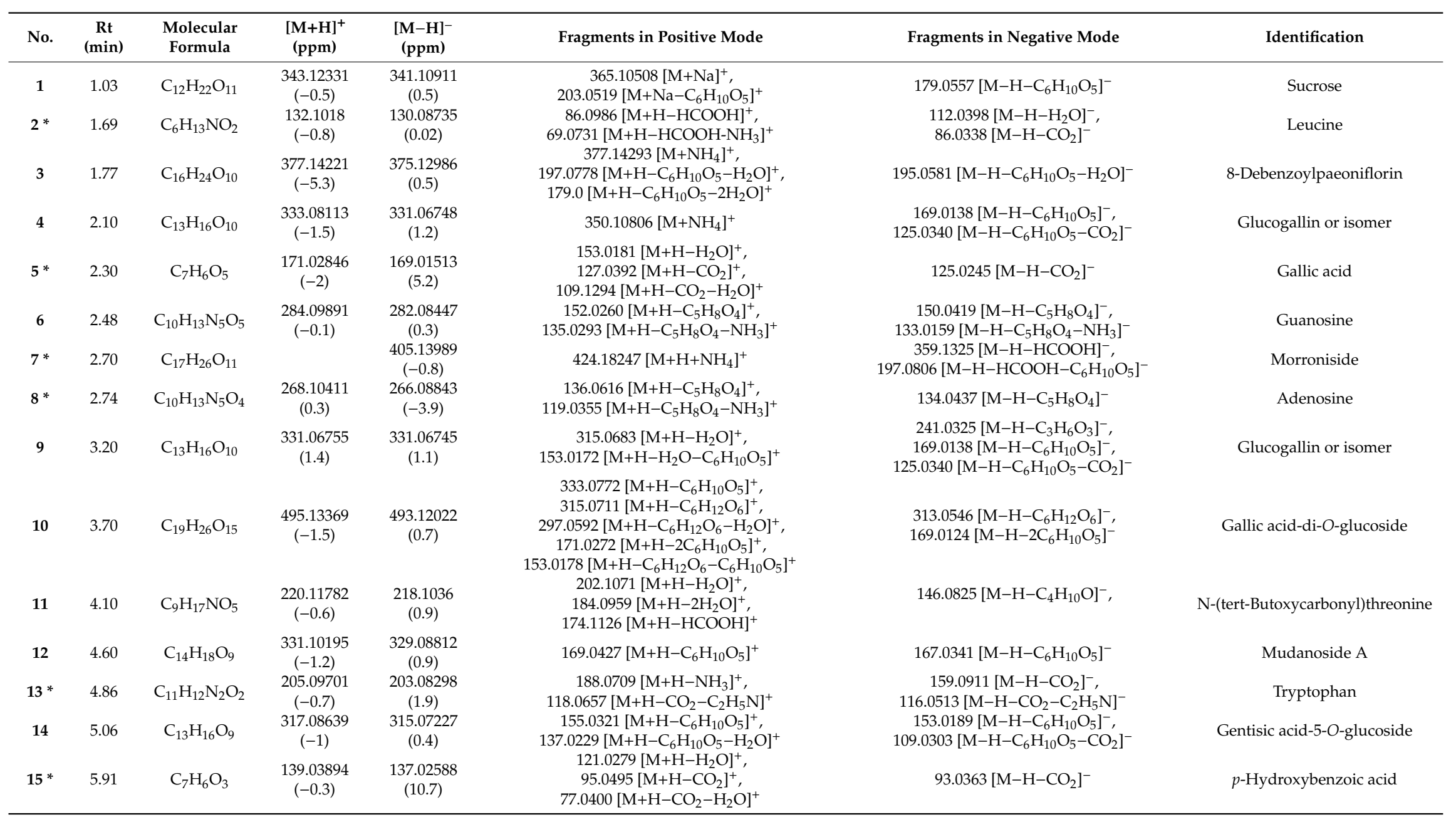


Table 2. Cont.

\begin{tabular}{|c|c|c|c|c|c|c|c|}
\hline No. & $\begin{array}{c}\mathrm{Rt} \\
(\mathrm{min})\end{array}$ & $\begin{array}{l}\text { Molecular } \\
\text { Formula }\end{array}$ & $\begin{array}{c}{[\mathrm{M}+\mathrm{H}]^{+}} \\
(\mathrm{ppm})\end{array}$ & $\begin{array}{c}{[\mathrm{M}-\mathrm{H}]^{-}} \\
(\mathrm{ppm})\end{array}$ & Fragments in Positive Mode & Fragments in Negative Mode & Identification \\
\hline 16 & 6.30 & $\mathrm{C}_{8} \mathrm{H}_{8} \mathrm{O}_{5}$ & $\begin{array}{c}185.04434 \\
(-0.6)\end{array}$ & $\begin{array}{c}183.03088 \\
(5.4)\end{array}$ & $\begin{array}{c}153.0188\left[\mathrm{M}+\mathrm{H}-\mathrm{CH}_{3} \mathrm{OH}\right]^{+}, \\
125.0239\left[\mathrm{M}+\mathrm{H}-\mathrm{CH}_{3} \mathrm{COOH}\right]^{+}, \\
107.0137\left[\mathrm{M}+\mathrm{H}-\mathrm{CH}_{3} \mathrm{COOH}-\mathrm{H}_{2} \mathrm{O}\right]^{+}\end{array}$ & $\begin{array}{c}168.0065\left[\mathrm{M}-\mathrm{H}-\mathrm{CH}_{3}\right]^{-} \\
124.0174\left[\mathrm{M}-\mathrm{H}-\mathrm{CH}_{3}-\mathrm{CO}_{2}\right]^{-}\end{array}$ & Methyl gallate \\
\hline 17 & 6.58 & $\mathrm{C}_{23} \mathrm{H}_{28} \mathrm{O}_{14}$ & $\begin{array}{l}529.15249 \\
(-5.1)\end{array}$ & $\begin{array}{l}527.14061 \\
\quad(0)\end{array}$ & $\begin{array}{c}493.1146\left[\mathrm{M}+\mathrm{H}-2 \mathrm{H}_{2} \mathrm{O}\right]^{+} \\
315.0648\left[\mathrm{M}+\mathrm{H}-\mathrm{C}_{7} \mathrm{H}_{4} \mathrm{O}_{5}-2 \mathrm{H}_{2} \mathrm{O}\right]^{+} \\
179.0679\left[\mathrm{C}_{10} \mathrm{H}_{11} \mathrm{O}_{3}\right]^{+}\end{array}$ & $\begin{array}{c}345.1178\left[\mathrm{M}-\mathrm{H}-\mathrm{C}_{8} \mathrm{H}_{6} \mathrm{O}_{5}\right]^{-} \\
313.0594\left[\mathrm{M}-\mathrm{H}-\mathrm{C}_{7} \mathrm{H}_{4} \mathrm{O}_{5}-2 \mathrm{H}_{2} \mathrm{O}\right]^{-} \\
271.0502,211.0201 \\
169.0146\left[\mathrm{C}_{10} \mathrm{H}_{11} \mathrm{O}_{3}\right]^{-}\end{array}$ & Debenzoylgalloylpaeoniflorin \\
\hline $18^{*}$ & 6.76 & $\mathrm{C}_{17} \mathrm{H}_{26} \mathrm{O}_{10}$ & $\begin{array}{l}391.16024 \\
\quad(0.9)\end{array}$ & $\begin{array}{l}389.14563 \\
\quad(0.8)\end{array}$ & & $\begin{array}{c}343.1424[\mathrm{M}-\mathrm{H}-\mathrm{HCOOH}]^{-} \\
181.0874\left[\mathrm{M}-\mathrm{H}-\mathrm{HCOOH}-\mathrm{C}_{6} \mathrm{H}_{10} \mathrm{O}_{5}\right]^{-} \\
163.0764\left[\mathrm{M}-\mathrm{H}-\mathrm{HCOOH}-\mathrm{C}_{6} \mathrm{H}_{10} \mathrm{O}_{5}-\mathrm{H}_{2} \mathrm{O}\right]^{-}\end{array}$ & Loganin \\
\hline 19 * & 7.15 & $\mathrm{C}_{17} \mathrm{H}_{24} \mathrm{O}_{10}$ & & $\begin{array}{l}387.12994 \\
\quad(0.7)\end{array}$ & & $\begin{array}{c}341.1357[\mathrm{M}-\mathrm{H}-\mathrm{HCOOH}]^{-} \\
179.0705\left[\mathrm{M}-\mathrm{H}-\mathrm{HCOOH}-\mathrm{C}_{6} \mathrm{H}_{10} \mathrm{O}_{5}\right]^{-}\end{array}$ & Geniposide \\
\hline 20 & 7.28 & $\mathrm{C}_{27} \mathrm{H}_{24} \mathrm{O}_{18}$ & $\begin{array}{c}637.10441 \\
(1.4)\end{array}$ & $\begin{array}{c}635.08956 \\
(0.9)\end{array}$ & $\begin{array}{c}467.0798\left[\mathrm{M}+\mathrm{H}-\mathrm{C}_{7} \mathrm{H}_{6} \mathrm{O}_{3}\right]^{+}, \\
297.0615\left[\mathrm{M}+\mathrm{H}-2 \mathrm{C}_{7} \mathrm{H}_{6} \mathrm{O}_{3}\right]^{+} \\
279.0415\left[\mathrm{M}+\mathrm{H}-2 \mathrm{C}_{7} \mathrm{H}_{6} \mathrm{O}_{3}-\mathrm{H}_{2} \mathrm{O}\right]^{+} \\
153.0171\left[\mathrm{C}_{7} \mathrm{H}_{5} \mathrm{O}_{4}\right]^{+}\end{array}$ & $\begin{array}{c}465.1075\left[\mathrm{M}-\mathrm{H}-\mathrm{C}_{7} \mathrm{H}_{6} \mathrm{O}_{3}\right]^{-}, \\
295.0506\left[\mathrm{M}-\mathrm{H}-2 \mathrm{C}_{7} \mathrm{H}_{6} \mathrm{O}_{3}\right]^{-}, \\
169.1023\left[\mathrm{C}_{7} \mathrm{H}_{5} \mathrm{O}_{5}\right]^{-}\end{array}$ & Trigalloyl glucose isomer \\
\hline 21 * & 7.53 & $\mathrm{C}_{23} \mathrm{H}_{28} \mathrm{O}_{12}$ & $\begin{array}{l}497.1651 \\
(-0.5)\end{array}$ & $\begin{array}{l}495.15083 \\
\quad(0.1)\end{array}$ & $\begin{array}{c}479.1557\left[\mathrm{M}+\mathrm{H}-\mathrm{H}_{2} \mathrm{O}\right]^{+}, \\
335.1123\left[\mathrm{M}+\mathrm{H}-\mathrm{C}_{6} \mathrm{H}_{10} \mathrm{O}_{5}\right]^{+}, \\
\left.\text {317.1018 [M+H-H- } \mathrm{H}_{2} \mathrm{O}-\mathrm{C}_{6} \mathrm{H}_{10} \mathrm{O}_{6}\right]^{+}, \\
197.0810\left[\mathrm{M}+\mathrm{H}-\mathrm{C}_{6} \mathrm{H}_{10} \mathrm{O}_{6}-\mathrm{C}_{7} \mathrm{H}_{6} \mathrm{O}_{3}\right]^{+}, \\
179.0704\left[\mathrm{M}+\mathrm{H}-\mathrm{C}_{6} \mathrm{H}_{10} \mathrm{O}_{6}-\mathrm{C}_{7} \mathrm{H}_{6} \mathrm{O}_{3}-\mathrm{H}_{2} \mathrm{O}\right]^{+}, \\
151.0752\left[\mathrm{M}+\mathrm{H}-\mathrm{C}_{6} \mathrm{H}_{10} \mathrm{O}_{6}-\mathrm{C}_{7} \mathrm{H}_{6} \mathrm{O}_{-}-2 \mathrm{H}_{2} \mathrm{O}\right]^{+}, \\
133.0643\left[\mathrm{M}+\mathrm{H}-\mathrm{C}_{6} \mathrm{H}_{10} \mathrm{O}_{6}-\mathrm{C}_{7} \mathrm{H}_{6} \mathrm{O}_{3}-3 \mathrm{H}_{2} \mathrm{O}\right]^{+}\end{array}$ & $\begin{array}{c}465.1446\left[\mathrm{M}-\mathrm{H}-\mathrm{CH}_{2} \mathrm{O}\right]^{-} \\
333.0998\left[\mathrm{M}-\mathrm{H}-\mathrm{C}_{6} \mathrm{H}_{10} \mathrm{O}_{5}\right]^{-} \\
195.0657\left[\mathrm{M}-\mathrm{H}-\mathrm{C}_{6} \mathrm{H}_{10} \mathrm{O}_{6}-\mathrm{C}_{7} \mathrm{H}_{6} \mathrm{O}_{3}\right]^{-} \\
165.0549\left[\mathrm{M}-\mathrm{H}-\mathrm{C}_{6} \mathrm{H}_{10} \mathrm{O}_{6}-\mathrm{C}_{7} \mathrm{H}_{6} \mathrm{O}_{3}-\mathrm{CH}_{2} \mathrm{O}\right]^{-} \\
137.0348 \\
{\left[\mathrm{M}-\mathrm{H}-\mathrm{C}_{6} \mathrm{H}_{10} \mathrm{O}_{6}-\mathrm{C}_{7} \mathrm{H}_{6} \mathrm{O}_{3}-\mathrm{CH}_{2} \mathrm{O}-\mathrm{H}_{2} \mathrm{O}\right]^{-}}\end{array}$ & Oxypaeoniflorin \\
\hline 22 & 8.23 & $\mathrm{C}_{21} \mathrm{H}_{22} \mathrm{O}_{11}$ & $\begin{array}{l}451.12391 \\
\quad(0.9)\end{array}$ & $\begin{array}{l}449.10937 \\
\quad(1)\end{array}$ & $\begin{array}{c}289.0705\left[\mathrm{M}+\mathrm{H}-\mathrm{C}_{6} \mathrm{H}_{10} \mathrm{O}_{5}\right]^{+} \\
271.0590\left[\mathrm{M}+\mathrm{H}-\mathrm{C}_{6} \mathrm{H}_{10} \mathrm{O}_{5}-\mathrm{H}_{2} \mathrm{O}\right]^{+} \\
153.0168\end{array}$ & $\begin{array}{c}287.0562\left[\mathrm{M}-\mathrm{H}-\mathrm{C}_{6} \mathrm{H}_{10} \mathrm{O}_{5}\right]^{-} \\
259.0618,151.0034\end{array}$ & Eriodictyol-7-O-glucoside \\
\hline 23 & 8.45 & $\mathrm{C}_{24} \mathrm{H}_{30} \mathrm{O}_{13}$ & & $\begin{array}{l}525.16213 \\
(1.5)\end{array}$ & $\begin{array}{c}544.202\left[\mathrm{M}+\mathrm{NH}_{4}\right]^{+}, \\
365.1232\left[\mathrm{M}+\mathrm{H}-\mathrm{C}_{6} \mathrm{H}_{10} \mathrm{O}_{5}\right]^{+} \\
347.1106\left[\mathrm{M}+\mathrm{H}-\mathrm{C}_{6} \mathrm{H}_{10} \mathrm{O}_{5}-\mathrm{H}_{2} \mathrm{O}\right]^{+} \\
197.0797\left[\mathrm{M}+\mathrm{H}-\mathrm{C}_{6} \mathrm{H}_{12} \mathrm{O}_{6}-\mathrm{C}_{8} \mathrm{H}_{6} \mathrm{O}_{3}\right]^{+} \\
179.0689\left[\mathrm{M}+\mathrm{H}-\mathrm{C}_{6} \mathrm{H}_{12} \mathrm{O}_{6}-\mathrm{C}_{8} \mathrm{H}_{6} \mathrm{O}_{3}-\mathrm{H}_{2} \mathrm{O}\right]^{+} \\
654.12968\left[\mathrm{M}+\mathrm{NH}_{4}\right]^{+},\end{array}$ & $\begin{array}{c}495.1558\left[\mathrm{M}-\mathrm{H}-\mathrm{CH}_{2} \mathrm{O}^{-},\right. \\
345.1044\left[\mathrm{M}-\mathrm{H}-\mathrm{C}_{6} \mathrm{H}_{12} \mathrm{O}_{6}\right]^{-}, \\
\text {195.0652 }\left[\mathrm{M}-\mathrm{H}-\mathrm{C}_{6} \mathrm{H}_{12} \mathrm{O}_{6}-\mathrm{C}_{8} \mathrm{H}_{6} \mathrm{O}_{3}\right]^{-} \\
177.0639\left[\mathrm{M}-\mathrm{H}-\mathrm{C}_{6} \mathrm{H}_{12} \mathrm{O}_{6}-\mathrm{C}_{8} \mathrm{H}_{6} \mathrm{O}_{3}-\mathrm{H}_{2} \mathrm{O}\right]^{-}\end{array}$ & Mudanpioside E \\
\hline 24 & 8.64 & $\mathrm{C}_{27} \mathrm{H}_{24} \mathrm{O}_{18}$ & & $\begin{array}{c}635.08955 \\
(0.9)\end{array}$ & $\begin{array}{c}619.0922\left[\mathrm{M}+\mathrm{H}-\mathrm{H}_{2} \mathrm{O}\right]^{+}, \\
449.0770\left[\mathrm{M}+\mathrm{H}-\mathrm{H}_{2} \mathrm{O}-\mathrm{C}_{7} \mathrm{H}_{6} \mathrm{O}_{5}\right]^{+}, \\
297.0615\left[\mathrm{M}+\mathrm{H}-\mathrm{H}_{2} \mathrm{O}-\mathrm{C}_{7} \mathrm{H}_{6} \mathrm{O}_{5}-\mathrm{C}_{7} \mathrm{H}_{4} \mathrm{O}_{4}\right]^{+}, \\
279.0476\left[\mathrm{M}+\mathrm{H}-2 \mathrm{H}_{2} \mathrm{O}-\mathrm{C}_{7} \mathrm{H}_{6} \mathrm{O}_{5}-\mathrm{C}_{7} \mathrm{H}_{4} \mathrm{O}_{4}\right]^{+}\end{array}$ & $\begin{array}{c}465.0666\left[\mathrm{M}-\mathrm{H}-\mathrm{C}_{7} \mathrm{H}_{6} \mathrm{O}_{5}\right]^{-}, \\
313.0554\left[\mathrm{M}-\mathrm{H}-\mathrm{C}_{7} \mathrm{H}_{6} \mathrm{O}_{5}-\mathrm{C}_{7} \mathrm{H}_{4} \mathrm{O}_{4}\right]^{-} \\
241.05094\left[\mathrm{M}-\mathrm{H}-\mathrm{C}_{7} \mathrm{H}_{6} \mathrm{O}_{5}-2 \mathrm{C}_{7} \mathrm{H}_{4} \mathrm{O}_{4}\right]^{-}\end{array}$ & Trigalloyl glucose \\
\hline
\end{tabular}


Table 2. Cont.

\begin{tabular}{|c|c|c|c|c|c|c|c|}
\hline No. & $\begin{array}{c}\mathrm{Rt} \\
(\mathrm{min})\end{array}$ & $\begin{array}{l}\text { Molecular } \\
\text { Formula }\end{array}$ & $\begin{array}{c}{[\mathrm{M}+\mathrm{H}]^{+}} \\
(\mathrm{ppm})\end{array}$ & $\begin{array}{c}{[\mathrm{M}-\mathrm{H}]^{-}} \\
(\mathrm{ppm})\end{array}$ & Fragments in Positive Mode & Fragments in Negative Mode & Identification \\
\hline 25 & 8.79 & $\mathrm{C}_{8} \mathrm{H}_{10} \mathrm{O}_{3}$ & $\begin{array}{l}155.07034 \\
(0.5)\end{array}$ & & $\begin{array}{c}140.0472\left[\mathrm{M}+\mathrm{H}-\mathrm{CH}_{3}\right]^{+} \\
123.0441\left[\mathrm{M}+\mathrm{H}-\mathrm{CH}_{4} \mathrm{O}\right]^{+}\end{array}$ & & 3,4-Dimethoxyphenol \\
\hline 26 & 9.20 & $\mathrm{C}_{27} \mathrm{H}_{30} \mathrm{O}_{17}$ & $\begin{array}{l}627.15612 \\
(0.9)\end{array}$ & $\begin{array}{c}625.14123 \\
(0.3)\end{array}$ & $\begin{array}{l}465.1022\left[\mathrm{M}+\mathrm{H}-\mathrm{C}_{6} \mathrm{H}_{10} \mathrm{O}_{5}\right]^{+}, \\
303.0497\left[\mathrm{M}+\mathrm{H}-2 \mathrm{C}_{6} \mathrm{H}_{10} \mathrm{O}_{5}\right]^{+}\end{array}$ & $\begin{array}{l}463.0928\left[\mathrm{M}-\mathrm{H}-\mathrm{C}_{6} \mathrm{H}_{10} \mathrm{O}_{5}\right]^{-} \\
301.0358\left[\mathrm{M}-\mathrm{H}-2 \mathrm{C}_{6} \mathrm{H}_{10} \mathrm{O}_{5}\right]^{-}\end{array}$ & Quercetin-O-di-glucoside or isomer \\
\hline 27 & 9.67 & $\mathrm{C}_{20} \mathrm{H}_{28} \mathrm{O}_{12}$ & $\begin{array}{l}461.16556 \\
\quad(0.5)\end{array}$ & $\begin{array}{l}459.14963 \\
(-2.6)\end{array}$ & $\begin{array}{c}299.1206\left[\mathrm{M}+\mathrm{H}-\mathrm{C}_{6} \mathrm{H}_{10} \mathrm{O}_{5}\right]^{+} \\
167.0707\left[\mathrm{M}+\mathrm{H}-\mathrm{C}_{6} \mathrm{H}_{10} \mathrm{O}_{5}-\mathrm{C}_{5} \mathrm{H}_{8} \mathrm{O}_{4}\right]^{+}\end{array}$ & $\begin{array}{c}297.0885\left[\mathrm{M}-\mathrm{H}-\mathrm{C}_{9} \mathrm{H}_{10} \mathrm{O}_{3}\right]^{-}, \\
165.0551\left[\mathrm{M}-\mathrm{H}-\mathrm{C}_{6} \mathrm{H}_{10} \mathrm{O}_{5}-\mathrm{C}_{5} \mathrm{H}_{8} \mathrm{O}_{4}\right]^{-}\end{array}$ & Paeonolide \\
\hline $28 *$ & 10.03 & $\mathrm{C}_{23} \mathrm{H}_{28} \mathrm{O}_{11}$ & $\begin{array}{l}481.17026 \\
(-0.4)\end{array}$ & $\begin{array}{l}479.15559 \\
(-0.6)\end{array}$ & $\begin{array}{c}319.1260\left[\mathrm{M}+\mathrm{H}-\mathrm{C}_{6} \mathrm{H}_{10} \mathrm{O}_{5}\right]^{+}, \\
301.1567\left[\mathrm{M}+\mathrm{H}-\mathrm{C}_{6} \mathrm{H}_{10} \mathrm{O}_{5}-\mathrm{H}_{2} \mathrm{O}^{+},\right. \\
179.0703\left[\mathrm{M}+\mathrm{H}-\mathrm{C}_{6} \mathrm{H}_{10} \mathrm{O}_{5}-\mathrm{H}_{2} \mathrm{O}-\mathrm{C}_{7} \mathrm{H}_{6} \mathrm{O}_{2}\right]^{+},\end{array}$ & $\begin{array}{c}449.1520\left[\mathrm{M}-\mathrm{H}-\mathrm{CH}_{2} \mathrm{O}^{-},\right. \\
327.1088\left[\mathrm{M}-\mathrm{H}-\mathrm{C}_{7} \mathrm{H}_{6} \mathrm{O}_{2}\right]^{-} \\
\text {165.0551 }\left[\mathrm{M}-\mathrm{H}-\mathrm{C}_{7} \mathrm{H}_{6} \mathrm{O}_{2}-\mathrm{C}_{6} \mathrm{H}_{10} \mathrm{O}_{5}\right]^{-}\end{array}$ & Paeoniflorin \\
\hline 29 & 10.27 & $\mathrm{C}_{27} \mathrm{H}_{30} \mathrm{O}_{16}$ & $\begin{array}{l}611.16221 \\
(2.5)\end{array}$ & $\begin{array}{l}609.14676 \\
(1.1)\end{array}$ & $\begin{array}{l}\left.\text { 449.1081 [M+H- } \mathrm{C}_{6} \mathrm{H}_{10} \mathrm{O}_{5}\right]^{+} \\
287.0552\left[\mathrm{M}+\mathrm{H}-2 \mathrm{C}_{6} \mathrm{H}_{10} \mathrm{O}_{5}\right]^{+}\end{array}$ & $\begin{array}{l}447.0961\left[\mathrm{M}-\mathrm{H}-\mathrm{C}_{6} \mathrm{H}_{10} \mathrm{O}_{5}\right]^{-} \\
285.0403\left[\mathrm{M}-\mathrm{H}-2 \mathrm{C}_{6} \mathrm{H}_{10} \mathrm{O}_{5}\right]^{-}\end{array}$ & Kaempferol-3,7-di-O-glucoside \\
\hline 30 & 10.48 & $\mathrm{C}_{30} \mathrm{H}_{32} \mathrm{O}_{16}$ & $\begin{array}{l}649.17332 \\
(-4.6)\end{array}$ & $\begin{array}{c}647.1606 \\
(-1.8)\end{array}$ & $\begin{array}{c}511.1395\left[\mathrm{M}+\mathrm{H}-\mathrm{C}_{7} \mathrm{H}_{6} \mathrm{O}_{3}\right]^{+}, \\
315.0712\left[\mathrm{M}+\mathrm{H}-\mathrm{C}_{17} \mathrm{H}_{18} \mathrm{O}_{7}\right]^{+} \\
153.0174\left[\mathrm{M}+\mathrm{H}-\mathrm{C}_{17} \mathrm{H}_{18} \mathrm{O}_{7}-\mathrm{C}_{6} \mathrm{H}_{10} \mathrm{O}_{5}\right]^{+}\end{array}$ & $\begin{array}{l}509.1335\left[\mathrm{M}-\mathrm{H}-\mathrm{C}_{7} \mathrm{H}_{6} \mathrm{O}_{3}\right]^{-} \\
313.0559\left[\mathrm{M}-\mathrm{H}-\mathrm{C}_{17} \mathrm{H}_{18} \mathrm{O}_{7}\right]^{-}\end{array}$ & Galloyloxypaeoniflorin \\
\hline 31 & 10.78 & $\mathrm{C}_{34} \mathrm{H}_{28} \mathrm{O}_{22}$ & $\begin{array}{l}789.11272 \\
(-2.3)\end{array}$ & $\begin{array}{l}787.10067 \\
(0.9)\end{array}$ & $\begin{array}{c}771.1010\left[\mathrm{M}+\mathrm{H}-\mathrm{H}_{2} \mathrm{O}\right]^{+} \\
619.0877\left[\mathrm{M}+\mathrm{H}-\mathrm{C}_{7} \mathrm{H}_{4} \mathrm{O}_{4}-\mathrm{H}_{2} \mathrm{O}\right]^{+} \\
449.0694\left[\mathrm{M}+\mathrm{H}-2 \mathrm{C}_{7} \mathrm{H}_{4} \mathrm{O}_{4}-2 \mathrm{H}_{2} \mathrm{O}\right]^{+} \\
279.0476\left[\mathrm{M}+\mathrm{H}-3 \mathrm{C}_{7} \mathrm{H}_{4} \mathrm{O}_{4}-3 \mathrm{H}_{2} \mathrm{O}\right]^{+}\end{array}$ & $\begin{array}{c}635.0985\left[\mathrm{M}-\mathrm{H}-\mathrm{C}_{7} \mathrm{H}_{4} \mathrm{O}_{4}\right]^{-} \\
617.0932\left[\mathrm{M}-\mathrm{H}-\mathrm{C}_{7} \mathrm{H}_{4} \mathrm{O}_{4}-\mathrm{H}_{2} \mathrm{O}\right]^{-} \\
465.0734\left[\mathrm{M}-\mathrm{H}-2 \mathrm{C}_{7} \mathrm{H}_{4} \mathrm{O}_{4}-\mathrm{H}_{2} \mathrm{O}\right]^{-} \\
295.0473\left[\mathrm{M}-\mathrm{H}-3 \mathrm{C}_{7} \mathrm{H}_{4} \mathrm{O}_{4}-2 \mathrm{H}_{2} \mathrm{O}\right]^{-}\end{array}$ & Teragalloyl glucose \\
\hline 32 & 11.28 & $\mathrm{C}_{28} \mathrm{H}_{32} \mathrm{O}_{18}$ & $\begin{array}{l}657.16586 \\
(-0.4)\end{array}$ & $\begin{array}{l}655.135 \\
(2.9)\end{array}$ & $\begin{array}{c}495.118\left[\mathrm{M}+\mathrm{H}-\mathrm{C}_{6} \mathrm{H}_{10} \mathrm{O}_{5}\right]^{+} \\
333.0606\left[\mathrm{M}+\mathrm{H}-2 \mathrm{C}_{6} \mathrm{H}_{10} \mathrm{O}_{5}\right]^{+}\end{array}$ & $331.0490\left[\mathrm{M}-\mathrm{H}-2 \mathrm{C}_{6} \mathrm{H}_{10} \mathrm{O}_{5}\right]-$, & Patuletin-3,5-di-O-glucoside \\
\hline 33 & 11.69 & $\mathrm{C}_{27} \mathrm{H}_{30} \mathrm{O}_{17}$ & $\begin{array}{l}627.1546 \\
(-1.6)\end{array}$ & $\begin{array}{l}625.1419 \\
(1.4)\end{array}$ & $\begin{array}{l}465.1038\left[\mathrm{M}+\mathrm{H}-\mathrm{C}_{6} \mathrm{H}_{10} \mathrm{O}_{5}\right]^{+} \\
303.0500\left[\mathrm{M}+\mathrm{H}-2 \mathrm{C}_{6} \mathrm{H}_{10} \mathrm{O}_{5}\right]^{+}\end{array}$ & $\begin{array}{c}301.0337\left[\mathrm{M}-\mathrm{H}-\mathrm{C}_{6} \mathrm{H}_{10} \mathrm{O}_{5}\right]^{-} \\
271.0245\left[\mathrm{M}-\mathrm{H}-2 \mathrm{C}_{6} \mathrm{H}_{10} \mathrm{O}_{5}-\mathrm{CH}_{2} \mathrm{O}\right]^{-}\end{array}$ & Quercetin-di-O-glucoside or isomer \\
\hline 34 & 12.21 & $\mathrm{C}_{28} \mathrm{H}_{32} \mathrm{O}_{17}$ & $\begin{array}{c}641.17086 \\
(-0.6)\end{array}$ & $\begin{array}{l}639.15895 \\
\quad(3.6)\end{array}$ & $\begin{array}{c}479.1168\left[\mathrm{M}+\mathrm{H}-\mathrm{C}_{6} \mathrm{H}_{10} \mathrm{O}_{5}\right]^{+}, \\
317.0652\left[\mathrm{M}+\mathrm{H}-2 \mathrm{C}_{6} \mathrm{H}_{10} \mathrm{O}_{5}\right]^{+} \\
771.110\left[\mathrm{M}+\mathrm{H}-\mathrm{C}_{7} \mathrm{H}_{6} \mathrm{O}_{5}\right]^{+}\end{array}$ & $\begin{array}{c}315.0507\left[\mathrm{M}-\mathrm{H}-2 \mathrm{C}_{6} \mathrm{H}_{10} \mathrm{O}_{5}\right]^{-} \\
769.1070\left[\mathrm{M}-\mathrm{H}-\mathrm{C}_{7} \mathrm{H}_{6} \mathrm{O}_{5}\right]^{-}\end{array}$ & Isorhamnetin-3,7-di-O-glucoside \\
\hline $35 *$ & 12.33 & $\mathrm{C}_{41} \mathrm{H}_{32} \mathrm{O}_{26}$ & $\begin{array}{l}941.12626 \\
(0.8)\end{array}$ & $\begin{array}{l}939.11461 \\
(3.9)\end{array}$ & $\begin{array}{c}431.0623\left[\mathrm{M}+\mathrm{H}-3 \mathrm{C}_{7} \mathrm{H}_{6} \mathrm{O}_{5}\right]^{+}, \\
279.0462\left[\mathrm{M}+\mathrm{H}-3 \mathrm{C}_{7} \mathrm{H}_{6} \mathrm{O}_{5}-\mathrm{C}_{6} \mathrm{H}_{10} \mathrm{O}_{5}\right]^{+}\end{array}$ & $\begin{array}{l}617.0931\left[\mathrm{M}-\mathrm{H}-\mathrm{C}_{7} \mathrm{H}_{6} \mathrm{O}_{5}-\mathrm{C}_{7} \mathrm{H}_{4} \mathrm{O}_{4}\right]^{-} \\
465.07051\left[\mathrm{M}-\mathrm{H}-\mathrm{C}_{7} \mathrm{H}_{6} \mathrm{O}_{5}-2 \mathrm{C}_{7} \mathrm{H}_{4} \mathrm{O}_{4}\right]^{-} \\
295.0430\left[\mathrm{M}-\mathrm{H}-2 \mathrm{C}_{7} \mathrm{H}_{6} \mathrm{O}_{5}-2 \mathrm{C}_{7} \mathrm{H}_{4} \mathrm{O}_{4}\right]^{-}\end{array}$ & 1,2,3,4,6-O-Pentagalloyl glucose \\
\hline 36 & 12.36 & $\mathrm{C}_{30} \mathrm{H}_{32} \mathrm{O}_{15}$ & $\begin{array}{l}633.18077 \\
(-1)\end{array}$ & $\begin{array}{l}631.16737 \\
\quad(0.8)\end{array}$ & $\begin{array}{c}315.0721\left[\mathrm{M}+\mathrm{H}-\mathrm{C}_{7} \mathrm{H}_{6} \mathrm{O}_{2}-\mathrm{C}_{10} \mathrm{H}_{12} \mathrm{O}_{10}\right]^{+} \\
179.0689\left[\mathrm{C}_{10} \mathrm{H}_{11} \mathrm{O}_{3}\right]^{+}\end{array}$ & $\begin{array}{c}613.1706\left[\mathrm{M}-\mathrm{H}-\mathrm{H}_{2} \mathrm{O}\right]^{-}, \\
509.1421\left[\mathrm{M}-\mathrm{H}-\mathrm{C}_{7} \mathrm{H}_{6} \mathrm{O}_{2}\right]^{-}, \\
313.1568\left[\mathrm{M}-\mathrm{H}-\mathrm{C}_{7} \mathrm{H}_{6} \mathrm{O}_{2}-\mathrm{C}_{10} \mathrm{H}_{12} \mathrm{O}_{10}\right]^{-}, \\
271.0539\left[\mathrm{M}-\mathrm{H}-\mathrm{C}_{7} \mathrm{H}_{6} \mathrm{O}_{2-}\right. \\
\left.\mathrm{C}_{10} \mathrm{H}_{12} \mathrm{O}_{10}-\mathrm{C}_{2} \mathrm{H}_{2} \mathrm{O}\right]^{-}\end{array}$ & Galloylpaeoniflorin \\
\hline
\end{tabular}


Table 2. Cont.

\begin{tabular}{|c|c|c|c|c|c|c|c|}
\hline No. & $\begin{array}{c}\mathrm{Rt} \\
(\mathrm{min})\end{array}$ & $\begin{array}{l}\text { Molecular } \\
\text { Formula }\end{array}$ & $\begin{array}{c}{[\mathrm{M}+\mathrm{H}]^{+}} \\
(\mathrm{ppm})\end{array}$ & $\begin{array}{c}{[\mathrm{M}-\mathrm{H}]^{-}} \\
(\mathrm{ppm})\end{array}$ & Fragments in Positive Mode & Fragments in Negative Mode & Identification \\
\hline 37 & 12.47 & $\mathrm{C}_{29} \mathrm{H}_{34} \mathrm{O}_{18}$ & $\begin{array}{c}671.18123 \\
(-0.8)\end{array}$ & $\begin{array}{l}669.16952 \\
(3.4)\end{array}$ & $\begin{array}{l}509.1271\left[\mathrm{M}+\mathrm{H}-\mathrm{C}_{6} \mathrm{H}_{10} \mathrm{O}_{5}\right]^{+} \\
347.0753\left[\mathrm{M}+\mathrm{H}-2 \mathrm{C}_{6} \mathrm{H}_{10} \mathrm{O}_{5}\right]^{+}\end{array}$ & $\begin{array}{c}345.0623\left[\mathrm{M}-\mathrm{H}-2 \mathrm{C}_{6} \mathrm{H}_{10} \mathrm{O}_{5}\right]^{-} \\
301.0361\left[\mathrm{M}-\mathrm{H}-2 \mathrm{C}_{6} \mathrm{H}_{10} \mathrm{O}_{5}-\mathrm{CO}_{2}\right]^{-}\end{array}$ & 6,3'-Dimethoxyquercetin-di-O-glucoside \\
\hline 38 & 12.98 & $\mathrm{C}_{29} \mathrm{H}_{34} \mathrm{O}_{17}$ & $\begin{array}{c}655.18661 \\
(-0.4)\end{array}$ & $\begin{array}{c}653.17535 \\
(4.6)\end{array}$ & $\begin{array}{c}509.1293\left[\mathrm{M}+\mathrm{H}-\mathrm{C}_{5} \mathrm{H}_{8} \mathrm{O}_{4}\right]^{+}, \\
347.0763\left[\mathrm{M}+\mathrm{H}-\mathrm{C}_{5} \mathrm{H}_{8} \mathrm{O}_{4}-\mathrm{C}_{6} \mathrm{H}_{10} \mathrm{O}_{5}\right]^{+}\end{array}$ & $\begin{array}{c}345.0552\left[\mathrm{M}-\mathrm{H}-\mathrm{C}_{5} \mathrm{H}_{8} \mathrm{O}_{4}-\mathrm{C}_{6} \mathrm{H}_{10} \mathrm{O}_{5}\right]^{-} \\
301.0335\left[\mathrm{M}-\mathrm{H}-\mathrm{C}_{5} \mathrm{H}_{8} \mathrm{O}_{4}-\mathrm{C}_{6} \mathrm{H}_{10} \mathrm{O}_{5}-\mathrm{C}_{2} \mathrm{H}_{4} \mathrm{O}\right]^{-}\end{array}$ & Monoxerutin \\
\hline 39 & 13.11 & $\mathrm{C}_{21} \mathrm{H}_{20} \mathrm{O}_{11}$ & $\begin{array}{c}449.10826 \\
()\end{array}$ & $\begin{array}{l}447.09399 \\
(1.6)\end{array}$ & $\begin{array}{c}287.0555\left[\mathrm{M}+\mathrm{H}-\mathrm{C}_{6} \mathrm{H}_{10} \mathrm{O}_{5}\right]^{+} \\
153.0181\end{array}$ & $285\left[\mathrm{M}-\mathrm{H}-\mathrm{C}_{6} \mathrm{H}_{10} \mathrm{O}_{5}\right]^{-}$ & Kaempferol-3-O-glucoside \\
\hline $40 *$ & 13.48 & $\mathrm{C}_{21} \mathrm{H}_{20} \mathrm{O}_{12}$ & & $\begin{array}{c}463.08881 \\
(1.3)\end{array}$ & & $\begin{array}{c}301.0354\left[\mathrm{M}-\mathrm{H}-\mathrm{C}_{6} \mathrm{H}_{10} \mathrm{O}_{5}\right]^{-} \\
151.0026\end{array}$ & Quercetin-3-O-glucoside \\
\hline 41 & 13.59 & $\mathrm{C}_{27} \mathrm{H}_{30} \mathrm{O}_{15}$ & $\begin{array}{l}595.16617 \\
(0.7)\end{array}$ & $\begin{array}{l}593.15348 \\
\quad(3.9)\end{array}$ & $287.0549\left[\mathrm{M}+\mathrm{H}-\mathrm{C}_{12} \mathrm{H}_{20} \mathrm{O}_{9}\right]^{+}$ & $285.0425\left[\mathrm{M}-\mathrm{H}-\mathrm{C}_{12} \mathrm{H}_{20} \mathrm{O}_{9}\right]^{-}$ & Kaempferol-3-O-rutinoside \\
\hline 42 & 13.66 & $\mathrm{C}_{30} \mathrm{H}_{32} \mathrm{O}_{14}$ & $\begin{array}{c}617.18694 \\
(0.7)\end{array}$ & $\begin{array}{c}615.17285 \\
(1.5)\end{array}$ & $\begin{array}{c}599.1479\left[\mathrm{M}+\mathrm{H}-\mathrm{H}_{2} \mathrm{O}\right]^{+} \\
479.1685\left[\mathrm{M}+\mathrm{H}-\mathrm{C}_{7} \mathrm{H}_{6} \mathrm{O}_{3}\right]^{+} \\
443.1294\left[\mathrm{M}+\mathrm{H}-\mathrm{C}_{7} \mathrm{H}_{6} \mathrm{O}_{3}-2 \mathrm{H}_{2} \mathrm{O}\right]^{+} \\
317.1017\left[\mathrm{M}+\mathrm{H}-\mathrm{C}_{7} \mathrm{H}_{6} \mathrm{O}_{3}-\mathrm{C}_{6} \mathrm{H}_{10} \mathrm{O}_{5}\right]^{+}, \\
179.0703\left[\mathrm{C}_{10} \mathrm{H}_{11} \mathrm{O}_{3}\right]^{+}\end{array}$ & $\begin{array}{c}431.1396\left[\mathrm{M}-\mathrm{H}-\mathrm{CH}_{2} \mathrm{O}_{2}-\mathrm{C}_{7} \mathrm{H}_{6} \mathrm{O}_{3}\right]^{-}, \\
281.06836 \\
{\left[\mathrm{M}-\mathrm{H}-\mathrm{CH}_{2} \mathrm{O}_{2}-\mathrm{C}_{7} \mathrm{H}_{6} \mathrm{O}_{3}-\mathrm{C}_{7} \mathrm{H}_{6} \mathrm{O}_{2}-\mathrm{CH}_{2} \mathrm{O}\right]^{-}}\end{array}$ & Mudanploside H \\
\hline 43 & 13.94 & $\mathrm{C}_{28} \mathrm{H}_{24} \mathrm{O}_{15}$ & $\begin{array}{c}601.11847 \\
(-0.5)\end{array}$ & $\begin{array}{l}599.10555 \\
(2.2)\end{array}$ & $287.0544\left[\mathrm{M}+\mathrm{H}-\mathrm{C}_{13} \mathrm{H}_{14} \mathrm{O}_{9}\right]^{+}$ & $285.0413\left[\mathrm{M}-\mathrm{H}-\mathrm{C}_{13} \mathrm{H}_{14} \mathrm{O}_{9}\right]^{-}$ & $\begin{array}{l}\text { Kaempferol-3-O- } \\
\text { (2"-O-galloyl)-glucoside }\end{array}$ \\
\hline 44 & 14.28 & $\mathrm{C}_{22} \mathrm{H}_{22} \mathrm{O}_{12}$ & $\begin{array}{l}479.1188 \\
(0.8)\end{array}$ & $\begin{array}{l}477.10532 \\
\quad(3.1)\end{array}$ & $317.0661\left[\mathrm{M}+\mathrm{H}-\mathrm{C}_{6} \mathrm{H}_{10} \mathrm{O}_{5}\right]^{+}$ & $\begin{array}{c}315.0537\left[\mathrm{M}-\mathrm{H}-\mathrm{C}_{6} \mathrm{H}_{10} \mathrm{O}_{5}\right]^{-}, \\
299.0214\left[\mathrm{M}-\mathrm{H}-\mathrm{C}_{6} \mathrm{H}_{10} \mathrm{O}_{6}\right]^{-} \\
271.0272\left[\mathrm{M}-\mathrm{H}-\mathrm{C}_{6} \mathrm{H}_{10} \mathrm{O}_{6}-\mathrm{H}_{2} \mathrm{O}\right]^{-} \\
255.0335,199.0371,171.0587\end{array}$ & Isorhamnetin-3-O-glucoside \\
\hline 45 & 14.31 & $\mathrm{C}_{21} \mathrm{H}_{20} \mathrm{O}_{10}$ & $\begin{array}{l}433.11321 \\
\quad(0.7)\end{array}$ & $\begin{array}{l}431.10019 \\
\quad(4.2)\end{array}$ & $\begin{array}{c}271.0600\left[\mathrm{M}+\mathrm{H}-\mathrm{C}_{6} \mathrm{H}_{10} \mathrm{O}_{5}\right]^{+}, \\
153.0176\end{array}$ & $269.0449\left[\mathrm{M}-\mathrm{H}-\mathrm{C}_{6} \mathrm{H}_{10} \mathrm{O}_{5}\right]^{-}$ & Apigenin-7-O-glucoside \\
\hline 46 * & 14.61 & $\mathrm{C}_{27} \mathrm{H}_{30} \mathrm{O}_{14}$ & $\begin{array}{c}579.1711 \\
(0.5)\end{array}$ & $\begin{array}{l}577.15834 \\
(3.6)\end{array}$ & $\begin{array}{c}433.1131\left[\mathrm{M}+\mathrm{H}-\mathrm{C}_{5} \mathrm{H}_{8} \mathrm{O}_{4}\right]^{+}, \\
271.0606\left[\mathrm{M}+\mathrm{H}-\mathrm{C}_{5} \mathrm{H}_{8} \mathrm{O}_{4}-\mathrm{C}_{6} \mathrm{H}_{10} \mathrm{O}_{5}\right]^{+}, \\
153.0177\end{array}$ & $269.0462\left[\mathrm{M}+\mathrm{H}-\mathrm{C}_{5} \mathrm{H}_{8} \mathrm{O}_{4}-\mathrm{C}_{6} \mathrm{H}_{10} \mathrm{O}_{5}\right] 7^{-}$ & Rhoifolin \\
\hline 47 & 14.91 & $\mathrm{C}_{28} \mathrm{H}_{32} \mathrm{O}_{15}$ & 0.5 & $\begin{array}{l}607.17007 \\
(5.3)\end{array}$ & $\begin{array}{c}463.1220\left[\mathrm{M}+\mathrm{H}-\mathrm{C}_{6} \mathrm{H}_{10} \mathrm{O}_{4}\right]^{+}, \\
301.0703\left[\mathrm{M}+\mathrm{H}-\mathrm{C}_{6} \mathrm{H}_{10} \mathrm{O}_{4}-\mathrm{C}_{6} \mathrm{H}_{10} \mathrm{O}_{5}\right]^{+}, \\
286.0461\left[\mathrm{M}+\mathrm{H}-\mathrm{C}_{6} \mathrm{H}_{10} \mathrm{O}_{4}-\mathrm{C}_{6} \mathrm{H}_{10} \mathrm{O}_{5}-\mathrm{CH}_{3}\right]^{+}\end{array}$ & $\begin{array}{c}443.0939\left[\mathrm{M}-\mathrm{H}-\mathrm{C}_{6} \mathrm{H}_{12} \mathrm{O}_{5}\right]^{-}, \\
299.0546\left[\mathrm{M}-\mathrm{H}-\mathrm{C}_{6} \mathrm{H}_{10} \mathrm{O}_{4}-\mathrm{C}_{6} \mathrm{H}_{10} \mathrm{O}_{5}\right]^{-}, \\
284.0301\left[\mathrm{M}-\mathrm{H}-\mathrm{C}_{5} \mathrm{H}_{8} \mathrm{O}_{4}-\mathrm{C}_{6} \mathrm{H}_{10} \mathrm{O}_{5}-\mathrm{CH}_{3}\right]^{-}\end{array}$ & Diosmin \\
\hline 48 & 14.95 & $\mathrm{C}_{22} \mathrm{H}_{22} \mathrm{O}_{12}$ & $\begin{array}{c}479.11832 \\
(-0.2)\end{array}$ & $\begin{array}{l}477.10464 \\
\quad(1.7)\end{array}$ & $317.0668\left[\mathrm{M}+\mathrm{H}-\mathrm{C}_{6} \mathrm{H}_{10} \mathrm{O}_{5}\right]^{+}$ & $285.0372\left[\mathrm{M}-\mathrm{H}-\mathrm{C}_{6} \mathrm{H}_{10} \mathrm{O}_{5}-\mathrm{CH}_{2} \mathrm{O}\right]^{-}$ & Isorhamnetin-7-O-glucoside \\
\hline 49 & 15.34 & $\mathrm{C}_{30} \mathrm{H}_{32} \mathrm{O}_{13}$ & $\begin{array}{c}601.18754 \\
(-6.7)\end{array}$ & $\begin{array}{l}599.17976 \\
\quad(4.6)\end{array}$ & $\begin{array}{c}461.1447\left[\mathrm{M}+\mathrm{H}-\mathrm{C}_{7} \mathrm{H}_{6} \mathrm{O}_{2}-\mathrm{H}_{2} \mathrm{O}\right]^{+} \\
443.1269\left[\mathrm{M}+\mathrm{H}-\mathrm{C}_{7} \mathrm{H}_{6} \mathrm{O}_{2}-2 \mathrm{H}_{2} \mathrm{O}\right]^{+} \\
301.1056\left[\mathrm{M}+\mathrm{H}-\mathrm{C}_{7} \mathrm{H}_{4} \mathrm{O}_{2}-\mathrm{C}_{7} \mathrm{H}_{4} \mathrm{O}_{3}-\mathrm{CO}_{2}\right]^{+} \\
283.08136 \\
{\left[\mathrm{M}+\mathrm{H}-\mathrm{C}_{7} \mathrm{H}_{4} \mathrm{O}_{2}-\mathrm{C}_{7} \mathrm{H}_{4} \mathrm{O}_{3}-\mathrm{CO}_{2}-\mathrm{H}_{2} \mathrm{O}\right]^{+}} \\
179.0695\left[\mathrm{C}_{10} \mathrm{H}_{11} \mathrm{O}_{3}\right]^{+}\end{array}$ & $\begin{array}{c}\left.\text { 447.1527 [M-H- } \mathrm{CH}_{2} \mathrm{O}-\mathrm{C}_{7} \mathrm{H}_{6} \mathrm{O}_{2}\right]^{-} \\
431.1379\left[\mathrm{M}-\mathrm{H}-\mathrm{CH}_{2} \mathrm{O}-\mathrm{C}_{7} \mathrm{H}_{6} \mathrm{O}_{3}\right]^{-} \\
281.0682\left[\mathrm{M}-\mathrm{H}-\mathrm{C}_{7} \mathrm{H}_{4} \mathrm{O}_{2}-\mathrm{C}_{7} \mathrm{H}_{4} \mathrm{O}_{3}-\mathrm{CO}_{2}-\mathrm{H}_{2} \mathrm{O}\right]^{-} \\
179.0329\left[\mathrm{C}_{10} \mathrm{H}_{11} \mathrm{O}_{3}\right]^{-}\end{array}$ & Mudanpioside C \\
\hline
\end{tabular}


Table 2. Cont

\begin{tabular}{|c|c|c|c|c|c|c|c|}
\hline No. & $\begin{array}{c}\mathrm{Rt} \\
(\mathrm{min})\end{array}$ & $\begin{array}{l}\text { Molecular } \\
\text { Formula }\end{array}$ & $\begin{array}{c}{[\mathrm{M}+\mathrm{H}]^{+}} \\
(\mathrm{ppm})\end{array}$ & $\begin{array}{c}{[\mathrm{M}-\mathrm{H}]^{-}} \\
(\mathrm{ppm})\end{array}$ & Fragments in Positive Mode & Fragments in Negative Mode & Identification \\
\hline 50 * & 15.69 & $\mathrm{C}_{9} \mathrm{H}_{10} \mathrm{O}_{3}$ & $\begin{array}{c}167.06995 \\
(-1.9)\end{array}$ & $\begin{array}{l}165.05663 \\
\quad(5.5)\end{array}$ & $\begin{array}{c}149.0737\left[\mathrm{M}+\mathrm{H}-\mathrm{H}_{2} \mathrm{O}\right]^{+} \\
121.0616\left[\mathrm{M}+\mathrm{H}-\mathrm{H}_{2} \mathrm{O}-\mathrm{CO}\right]^{+}\end{array}$ & $\begin{array}{c}150.0318\left[\mathrm{M}-\mathrm{H}-\mathrm{CH}_{3}\right]^{-}, \\
135.0098\left[\mathrm{M}-\mathrm{H}-\mathrm{CH}_{2} \mathrm{O}\right]^{-} \\
122.0377\left[\mathrm{M}-\mathrm{H}-\mathrm{CH}_{3}-\mathrm{CO}\right]^{-}\end{array}$ & Paeonol \\
\hline 51 & 15.78 & $\mathrm{C}_{30} \mathrm{H}_{32} \mathrm{O}_{13}$ & & $\begin{array}{l}599.18003 \\
\quad(5)\end{array}$ & & $\begin{array}{c}569.1748\left[\mathrm{M}-\mathrm{H}-\mathrm{CH}_{2} \mathrm{O}\right]^{-} \\
447.1519\left[\mathrm{M}-\mathrm{H}-\mathrm{CH}_{2} \mathrm{O}-\mathrm{C}_{7} \mathrm{H}_{6} \mathrm{O}_{2}\right]^{-}\end{array}$ & Benzoyloxypaeoniflorin \\
\hline 52 & 16.14 & $\mathrm{C}_{31} \mathrm{H}_{34} \mathrm{O}_{14}$ & $\begin{array}{l}631.20136 \\
(-1.2)\end{array}$ & $\begin{array}{l}629.19181 \\
(6.7)\end{array}$ & $\begin{array}{c}\left.\text { 457.1797 [M+H- }-\mathrm{C}_{8} \mathrm{H}_{6} \mathrm{O}_{4}-\mathrm{H}_{2} \mathrm{O}\right]^{+}, \\
\text {317.1009 }\left[\mathrm{M}+\mathrm{H}-\mathrm{C}_{7} \mathrm{H}_{6} \mathrm{O}_{2}-\mathrm{C}_{8} \mathrm{H}_{6} \mathrm{O}_{4}-\mathrm{H}_{2} \mathrm{O}\right]^{+}, \\
297.1009\left[\mathrm{M}+\mathrm{H}-\mathrm{C}_{7} \mathrm{H}_{6} \mathrm{O}_{2}-\mathrm{C}_{8} \mathrm{H}_{6} \mathrm{O}_{4}-2 \mathrm{H}_{2} \mathrm{O}\right]^{+}, \\
279.1108\left[\mathrm{M}+\mathrm{H}-\mathrm{C}_{7} \mathrm{H}_{6} \mathrm{O}_{2}-\mathrm{C}_{8} \mathrm{H}_{6} \mathrm{O}_{4}-3 \mathrm{H}_{2} \mathrm{O}\right]^{+}, \\
\quad 179.0692\left[\mathrm{C}_{10} \mathrm{H}_{11} \mathrm{O}_{3}\right]^{+}\end{array}$ & $\begin{array}{c}477.1511\left[\mathrm{M}-\mathrm{H}-\mathrm{C}_{8} \mathrm{H}_{6} \mathrm{O}_{3}\right]^{-}, \\
333.1206\left[\mathrm{M}-\mathrm{H}-\mathrm{C}_{7} \mathrm{H}_{6} \mathrm{O}_{2}-\mathrm{C}_{8} \mathrm{H}_{6} \mathrm{O}_{4}\right]^{-}\end{array}$ & Mudanpioside J \\
\hline 53 * & 16.95 & $\mathrm{C}_{15} \mathrm{H}_{10} \mathrm{O}_{6}$ & & $\begin{array}{c}285.04116 \\
(2.4)\end{array}$ & $175.0407,133.0318$ & $151.0031,133.0278$ & Luteolin \\
\hline 54 * & 17.47 & $\mathrm{C}_{30} \mathrm{H}_{32} \mathrm{O}_{12}$ & $\begin{array}{l}585.19501 \\
(-2.8)\end{array}$ & $\begin{array}{l}583.1816 \\
(-0.9)\end{array}$ & $\begin{array}{c}445.1496\left[\mathrm{M}+\mathrm{H}-\mathrm{C}_{7} \mathrm{H}_{6} \mathrm{O}_{2}-\mathrm{H}_{2} \mathrm{O}\right]^{+} \\
427.1407\left[\mathrm{M}+\mathrm{H}-\mathrm{C}_{7} \mathrm{H}_{6} \mathrm{O}_{2}-2 \mathrm{H}_{2} \mathrm{O}\right]^{+}, \\
179.0698\left[\mathrm{C}_{10} \mathrm{H}_{11} \mathrm{O}_{3}\right]^{+}\end{array}$ & $\begin{array}{c}461.1775\left[\mathrm{M}-\mathrm{H}-\mathrm{C}_{7} \mathrm{H}_{6} \mathrm{O}_{2}\right]^{-} \\
343.1562\left[\mathrm{M}-\mathrm{H}-\mathrm{C}_{7} \mathrm{H}_{4} \mathrm{O}_{2}-\mathrm{C}_{7} \mathrm{H}_{4} \mathrm{O}_{3}\right]^{-}\end{array}$ & Benzoylpaeoniflorin \\
\hline 55 * & 18.27 & $\mathrm{C}_{15} \mathrm{H}_{10} \mathrm{O}_{5}$ & & $\begin{array}{c}269.0465 \\
(3.5)\end{array}$ & & $225.0553,149.0235,117.0346$ & Apigenin \\
\hline 56 & 18.49 & $\mathrm{C}_{16} \mathrm{H}_{12} \mathrm{O}_{6}$ & $\begin{array}{l}301.07102 \\
(1.2)\end{array}$ & $\begin{array}{l}299.05704 \\
(3.1)\end{array}$ & $\begin{array}{c}286.0479\left[\mathrm{M}+\mathrm{H}-\mathrm{CH}_{3}\right]^{+} \\
258.0531\left[\mathrm{M}+\mathrm{H}-\mathrm{CH}_{3}-\mathrm{CO}\right]^{+} \\
153.0158\end{array}$ & $\begin{array}{c}284.0352\left[\mathrm{M}-\mathrm{H}-\mathrm{CH}_{3}\right]^{-} \\
256.0408\left[\mathrm{M}-\mathrm{H}-\mathrm{CH}_{3}-\mathrm{CO}\right]^{-}\end{array}$ & Chrysoeriol \\
\hline 57 & 19.66 & $\mathrm{C}_{18} \mathrm{H}_{32} \mathrm{O}_{5}$ & $\begin{array}{l}329.23227 \\
\quad(0.1)\end{array}$ & $\begin{array}{l}327.21889 \\
(3.7)\end{array}$ & $\begin{array}{c}293.1959\left[\mathrm{M}+\mathrm{H}-2 \mathrm{H}_{2} \mathrm{O}\right]^{+} \\
275.1959\left[\mathrm{M}+\mathrm{H}-2 \mathrm{H}_{2} \mathrm{O}\right]^{+} \\
225.1488,185.1171,161.1375 \\
119.0830,105.0700 \\
3132713\left[\mathrm{M}+\mathrm{H}-\mathrm{H}_{2} \mathrm{O}^{+}\right.\end{array}$ & $\begin{array}{c}309.2062\left[\mathrm{M}-\mathrm{H}-\mathrm{H}_{2} \mathrm{O}\right]^{-} \\
291,1961\left[\mathrm{M}-\mathrm{H}-2 \mathrm{H}_{2} \mathrm{O}\right]^{-} \\
229.1448,211.1341,171.1038\end{array}$ & Malyngic acid \\
\hline 58 & 20.57 & $\mathrm{C}_{18} \mathrm{H}_{34} \mathrm{O}_{5}$ & $\begin{array}{c}331.2482 \\
(0.9)\end{array}$ & $\begin{array}{l}329.23479 \\
(4.4)\end{array}$ & $\begin{array}{l}295.2205\left[\mathrm{M}+\mathrm{H}-2 \mathrm{H}_{2} \mathrm{O}\right]^{+} \\
277.2121\left[\mathrm{M}+\mathrm{H}-3 \mathrm{H}_{2} \mathrm{O}\right]^{+} \\
213.1447,195.1343,171.1285 \\
271.2277\left[\mathrm{M}+\mathrm{H}-\mathrm{H}_{2} \mathrm{O}\right]^{+}\end{array}$ & $\begin{array}{c}311.1223\left[\mathrm{M}-\mathrm{H}-\mathrm{H}_{2} \mathrm{O}\right]^{-} \\
229.1447, \\
\text {, } 211.1327,171.023\end{array}$ & 9,12,13-Trihydroxyoctadec-10-enoic acid \\
\hline 59 & 21.15 & $\mathrm{C}_{16} \mathrm{H}_{32} \mathrm{O}_{4}$ & $\begin{array}{l}289.23763 \\
\quad(1.0)\end{array}$ & $\begin{array}{l}287.22468 \\
\quad(6.6)\end{array}$ & $\begin{array}{c}253.2155\left[\mathrm{M}+\mathrm{H}-2 \mathrm{H}_{2} \mathrm{O}\right]^{+}, \\
235.2064\left[\mathrm{M}+\mathrm{H}-3 \mathrm{H}_{2} \mathrm{O}\right]^{+}, \\
217.1897\left[\mathrm{M}+\mathrm{H}-4 \mathrm{H}_{2} \mathrm{O}\right]^{+}, \\
161.1364,135.1159,111.1162\end{array}$ & $\begin{array}{l}269.2127\left[\mathrm{M}-\mathrm{H}-\mathrm{H}_{2} \mathrm{O}\right]^{-} \\
241.2167[\mathrm{M}-\mathrm{H}-\mathrm{HCOOH}]^{-}\end{array}$ & 3,12-Dihydroxyhexadecanoic acid \\
\hline 60 & 24.79 & $\mathrm{C}_{18} \mathrm{H}_{30} \mathrm{O}_{3}$ & $\begin{array}{l}295.22674 \\
(-0.1)\end{array}$ & $\begin{array}{l}293.21325 \\
(3.5)\end{array}$ & $\begin{array}{c}277.2145\left[\mathrm{M}+\mathrm{H}-\mathrm{H}_{2} \mathrm{O}\right]^{+} \\
231.1648\left[\mathrm{M}+\mathrm{H}-3 \mathrm{H}_{2} \mathrm{O}\right]^{+} \\
207.1426,171.1093,147.1158\end{array}$ & $\begin{array}{l}275.2024\left[\mathrm{M}-\mathrm{H}-\mathrm{H}_{2} \mathrm{O}\right]^{-} \\
\quad 223.134,195.1395\end{array}$ & 9-Oxooctadeca-10,12-dienoic acid \\
\hline
\end{tabular}


Table 2. Cont.

\begin{tabular}{|c|c|c|c|c|c|c|c|}
\hline No. & $\begin{array}{c}\mathrm{Rt} \\
(\mathrm{min})\end{array}$ & $\begin{array}{c}\text { Molecular } \\
\text { Formula }\end{array}$ & $\begin{array}{c}{[\mathrm{M}+\mathrm{H}]^{+}} \\
(\mathrm{ppm})\end{array}$ & $\begin{array}{c}{[\mathrm{M}-\mathrm{H}]^{-}} \\
(\mathrm{ppm})\end{array}$ & Fragments in Positive Mode & Fragments in Negative Mode & Identification \\
\hline 61 & 25.57 & $\mathrm{C}_{18} \mathrm{H}_{32} \mathrm{O}_{3}$ & $\begin{array}{c}297.24039 \\
(-6.8)\end{array}$ & $\begin{array}{l}295.22859 \\
(2.4)\end{array}$ & $\begin{array}{c}281.0520\left[\mathrm{M}+\mathrm{H}-\mathrm{H}_{2} \mathrm{O}\right]^{+}, \\
191.0009,133.0103\end{array}$ & $\begin{array}{c}277.21992\left[\mathrm{M}-\mathrm{H}-\mathrm{H}_{2} \mathrm{O}\right]^{-} \\
195.1402\end{array}$ & 13-Hydroxy-9,11-octadecadienoic acid \\
\hline 62 & 26.63 & $\mathrm{C}_{30} \mathrm{H}_{48} \mathrm{O}_{4}$ & $\begin{array}{c}473.36163 \\
(-1.9)\end{array}$ & $\begin{array}{l}471.34891 \\
\text { (2) }\end{array}$ & $427.3607[\mathrm{M}+\mathrm{H}-\mathrm{HCOOH}]^{+}$ & $425.2233[\mathrm{M}-\mathrm{H}-\mathrm{HCOOH}]^{-}$ & Hederagenin \\
\hline 63 & 28.34 & $\mathrm{C}_{30} \mathrm{H}_{48} \mathrm{O}_{3}$ & $\begin{array}{l}457.36722 \\
(-0.9)\end{array}$ & $\begin{array}{l}455.35374 \\
(1.5)\end{array}$ & $\begin{array}{c}439.3579\left[\mathrm{M}+\mathrm{H}-\mathrm{H}_{2} \mathrm{O}\right]^{+} \\
411.3613[\mathrm{M}+\mathrm{H}-\mathrm{HCOOH}]^{+} \\
393.3485\left[\mathrm{M}+\mathrm{H}-\mathrm{HCOOH}-\mathrm{H}_{2} \mathrm{O}\right]^{+}\end{array}$ & $409.2504[\mathrm{M}-\mathrm{H}-\mathrm{HCOOH}]^{-}$ & Oleanolic acid \\
\hline $64 *$ & 29.21 & $\mathrm{C}_{16} \mathrm{H}_{32} \mathrm{O}_{2}$ & $\begin{array}{l}257.24755 \\
\quad(0.2)\end{array}$ & $\begin{array}{c}255.23339 \\
\quad(1.7)\end{array}$ & $229.2057[\mathrm{M}+\mathrm{H}-\mathrm{CO}]^{+}$ & $237.1230\left[\mathrm{M}-\mathrm{H}-\mathrm{H}_{2} \mathrm{O}\right]^{-}$ & Hexadecanoic acid \\
\hline 65 & 29.42 & $\mathrm{C}_{22} \mathrm{H}_{44} \mathrm{O}_{3}$ & $\begin{array}{l}357.33656 \\
(0.7)\end{array}$ & $\begin{array}{l}355.32323 \\
(4.1)\end{array}$ & $\begin{array}{l}339.3238\left[\mathrm{M}+\mathrm{H}-\mathrm{H}_{2} \mathrm{O}\right]^{+} \\
321.3230\left[\mathrm{M}+\mathrm{H}-2 \mathrm{H}_{2} \mathrm{O}\right]^{+} \\
303.3031\left[\mathrm{M}+\mathrm{H}-3 \mathrm{H}_{2} \mathrm{O}\right]^{+}\end{array}$ & $309.3120[\mathrm{M}-\mathrm{H}-\mathrm{HCOOH}]^{-}$ & 2-Hydroxybehenic acid \\
\hline $66 *$ & 29.50 & $\mathrm{C}_{18} \mathrm{H}_{34} \mathrm{O}_{2}$ & $\begin{array}{c}283.26342 \\
(0.9)\end{array}$ & $\begin{array}{l}281.24868 \\
(0.3)\end{array}$ & $\begin{array}{c}265.2497\left[\mathrm{M}+\mathrm{H}-\mathrm{H}_{2} \mathrm{O}\right]^{+} \\
247.2429\left[\mathrm{M}+\mathrm{H}-2 \mathrm{H}_{2} \mathrm{O}\right]^{+} \\
237.5873[\mathrm{M}+\mathrm{H}-\mathrm{HCOOH}]^{+}\end{array}$ & $263.0356\left[\mathrm{M}-\mathrm{H}-\mathrm{H}_{2} \mathrm{O}\right]^{-}$ & 9-Octadecenoic acid \\
\hline 67 & 29.38 & $\mathrm{C}_{27} \mathrm{H}_{44} \mathrm{O}_{2}$ & $\begin{array}{l}401.34101 \\
(-1)\end{array}$ & $\begin{array}{l}399.32889 \\
\quad(5.1)\end{array}$ & $283.3072\left[\mathrm{M}+\mathrm{H}-\mathrm{H}_{2} \mathrm{O}\right]^{+}$ & $355.3114\left[\mathrm{M}-\mathrm{H}-\mathrm{CO}_{2}\right]^{-}$ & Dehydrotocopherol \\
\hline $68^{*}$ & 29.65 & $\mathrm{C}_{18} \mathrm{H}_{36} \mathrm{O}_{2}$ & & $\begin{array}{c}283.26451 \\
(0.9)\end{array}$ & & $265.2659\left[\mathrm{M}-\mathrm{H}-\mathrm{H}_{2} \mathrm{O}\right]^{-}$ & Octadecanoic acid \\
\hline
\end{tabular}

* The compound was identified by the comparison with reference standard. 
Monoterpenoids are present as ubiquitous chemical compounds in P. suffruticosa, which are characterized by two isoprene units and have the molecular formula $\mathrm{C}_{10} \mathrm{H}_{16}$. Among them, paeoniflorin (28), oxypaeoniflorin (21), and benzoylpaeoniflorin (54) were precisely identified by the comparison to their reference standards, respectively. Analyzing the mass spectrogram, the fragment ions were usually generated by losing the units of glucose residue $\left(\mathrm{C}_{6} \mathrm{H}_{10} \mathrm{O}_{5}, 162 \mathrm{Da}\right)$, benzoic acid residue $\left(\mathrm{C}_{7} \mathrm{H}_{6} \mathrm{O}_{2}, 122 \mathrm{Da}\right)$, and hydroxybenzoic acid residue $\left(\mathrm{C}_{7} \mathrm{H}_{6} \mathrm{O}_{3}, 138 \mathrm{Da}\right)$. Therefore, compound 3 with $\mathrm{m} / \mathrm{z} 375.12986$ (calculated to be $\mathrm{C}_{16} \mathrm{H}_{24} \mathrm{O}_{10}$ ), compound 17 with $\mathrm{m} / z 527.14061$ (calculated to be $\mathrm{C}_{23} \mathrm{H}_{28} \mathrm{O}_{14}$ ), compound 23 with $m / z 525.16213$ (calculated to be $\mathrm{C}_{24} \mathrm{H}_{29} \mathrm{O}_{13}$ ), compound 30 with $\mathrm{m} / \mathrm{z} 647.16060$ (calculated to be $\mathrm{C}_{30} \mathrm{H}_{32} \mathrm{O}_{16}$ ), compound 36 with $\mathrm{m} / \mathrm{z} 631.16737$ (calculated to be $\mathrm{C}_{30} \mathrm{H}_{32} \mathrm{O}_{15}$ ), compound 42 with $\mathrm{m} / \mathrm{z} 615.17285$ (calculated to be $\mathrm{C}_{30} \mathrm{H}_{32} \mathrm{O}_{14}$ ), compound 49 with $\mathrm{m} / \mathrm{z} 599.17976$ (calculated to be $\mathrm{C}_{30} \mathrm{H}_{32} \mathrm{O}_{13}$ ), compound 51 with $\mathrm{m} / 2599.18003$ (calculated to be $\mathrm{C}_{30} \mathrm{H}_{32} \mathrm{O}_{13}$ ), and compound 52 with $\mathrm{m} / z 629.19181$ (calculated to be $\mathrm{C}_{31} \mathrm{H}_{34} \mathrm{O}_{14}$ ) in negative mode were tentatively identified as 8-debenzoylpaeoniflorin [28], debenzoygalloypeaoniflorin, mudanpioside E, galloyoxypaeoniflorin, galloylpaeonifflorin, benzoyloxypaeoniflorin, mudanploside $\mathrm{H}$, mudanpioside C, benzoloxypaeoniflorin, and mudanpioside J, respectively [29].

Flavonoids, especially quercetin, kaempferol, isorhamnetin, apigenin and their derivatives, are another set of components also identified in P. suffruticosa [30]. Their fragment behaviors have been investigated very well in positive and negative ion modes. Usually, the [aglycone- $\mathrm{H}]^{-}$ion is generated by loss of the linkage of sugars and thereafter followed by Ret-Diels-Alder (RDA) dissociation, subsequently generating $\mathrm{m} / \mathrm{z} 179$ and 151 ions [31]. Compounds 46, 53, and 55 were undeniably identified as rhoifolin, luteolin, and apigenin, respectively. According to the fragmentation mechanism, compound 45 were inferred as apigenin-7-O-glucoside with $\mathrm{m} / \mathrm{z}$ at 431.10019 in negative ion mode [30]. Kaempferol is an isomer of luteolin with molecular formula $\mathrm{C}_{15} \mathrm{H}_{10} \mathrm{O}_{6}$. Compounds 29, 39, 41, and 43 were inferred as kaempferol-3,7-O-di-glucoside, kaempferol-3-O-glucoside, kaempferol-3-O-rutinoside, and kaempferol-3-O-(2"'-O-galloyl)-glucoside [10,30]. Isorhamnetin with molecular formula $\mathrm{C}_{16} \mathrm{H}_{12} \mathrm{O}_{7}$, was $30 \mathrm{Da}\left(\mathrm{CH}_{2} \mathrm{O}\right)$ higher than luteolin. Compounds 44 and 48 were isomers with molecular formula of $\mathrm{C}_{22} \mathrm{H}_{22} \mathrm{O}_{12}$. The fragment ion at $\mathrm{m} / \mathrm{z} 317$ was yielded by loss of glucose. Thus they were tentatively identified as isorhamnetin-3-O-glucoside and isorhamnetin-7-O-glucoside, respectively. Compound 34 gave an $[\mathrm{M}-\mathrm{H}]^{-}$ion at $m / z 639.15895$ (calculated as $\mathrm{C}_{28} \mathrm{H}_{31} \mathrm{O}_{17}$ ) and was inferred as isorhamnetin-3,7-di-O-glucoside [32]. Quercetin was $\mathrm{C}_{15} \mathrm{H}_{10} \mathrm{O}_{7}, 16 \mathrm{Da}(\mathrm{O})$ higher than luteolin. Compound 40 was quercetin-3-O-glucoside with an [aglycone-H] $]^{-}$ion at $\mathrm{m} / \mathrm{z} 301.0354$ by loss of glucose residue [10]. Compounds 26 and 33 were isomers, which gave $[\mathrm{M}-\mathrm{H}]^{-}$at $m / z 625$ and were tentatively identified as quercetin-3,7-di-O-glucoside or its isomer [32]. Compound 37 was $30 \mathrm{Da}$ $\left(\mathrm{CH}_{2} \mathrm{O}\right)$ higher than compound 34 and was inferred as 6,3'-dimethoxyquercetin-7-O-di-glucoside with $\mathrm{m} / \mathrm{z}$ at 669.16952. Compound 22 (eriodictyol-7-O-glucoside) was calculated as $\mathrm{C}_{21} \mathrm{H}_{22} \mathrm{O}_{11}$ and generated a fragment ion at $\mathrm{m} / \mathrm{z} 287$ by loss of one glycoside. Compound 32 (patuletin-3,5-di-O-glucoside) was calculated as $\mathrm{C}_{28} \mathrm{H}_{32} \mathrm{O}_{18}$, and generated a fragment ion at $\mathrm{m} / \mathrm{z} 331$ by loss of two glycosides [32]. Compound 38 was inferred as monoxerutin with a quasi-molecular ion at $\mathrm{m} / \mathrm{z}$ 653.17535. Diosmin (47) gave a quasi-molecular ion at $\mathrm{m} / \mathrm{z}$ 607.17007, and subsequently generated an ion of 299 by loss of a rutinoside. Compound 56 has $30 \mathrm{Da}\left(\mathrm{CH}_{2} \mathrm{O}\right)$ more than apigenin, and it was identified as chrysoeriol with an $[\mathrm{M}-\mathrm{H}]^{-}$ion at $\mathrm{m} / \mathrm{z} 299.05704$.

There were 14 phenols and derivatives found in the four extracts of P. suffruticosa flowers. Compounds 5, 15, 35, and 50 were directly identified as gallic acid, $p$-hydroxybenzoic acid, 1,2,3,4,6-O-pentagalloyl glucose, and paeonol by the comparison of their reference standards, respectively. Compounds 4 and 9 were a pair of isomers, which showed 162 Da more than gallic acid, suggesting the presence of $\mathrm{C}_{6} \mathrm{H}_{10} \mathrm{O}_{5}$. They were tentatively identified as glucogallin or isomer. Interestingly, compound $\mathbf{1 0}$ gave 324 Da more than gallic acid, suggesting the presence of two $\mathrm{C}_{6} \mathrm{H}_{10} \mathrm{O}_{5}$ [33]. Compound 16 showed $\mathrm{CH}_{2}$ (14 Da) more than gallic acid, and was referred to be methyl gallate [29]. In mass spectrum, compound 12 was determined to be $\mathrm{C}_{14} \mathrm{H}_{18} \mathrm{O}_{9}$ and yield an ion at $\mathrm{m} / \mathrm{z}$ $167.0341\left[\mathrm{M}-\mathrm{H}-\mathrm{C}_{6} \mathrm{H}_{10} \mathrm{O}_{5}\right]^{-}$. It was tentatively identified as mudanoside A [29]. Compound 14 gave 
an $[\mathrm{M}-\mathrm{H}]^{-}$ion at $\mathrm{m} / \mathrm{z} 315.07227$, corresponding to $\mathrm{C}_{13} \mathrm{H}_{16} \mathrm{O}_{9}$. It yielded daughter ions by successive losses of $\mathrm{C}_{6} \mathrm{H}_{10} \mathrm{O}_{5}, \mathrm{CO}_{2}$ and was inferred to be gentisic acid-5-O-glucoside. Compounds 24 and 31 were tentatively identified as trigalloyl glucose and teragalloyl glucose. Compound $\mathbf{2 0}$ was an isomer of trigalloyl glucose with a characteristic structure of $\mathrm{C}_{7} \mathrm{H}_{6} \mathrm{O}_{3}$. Compound 25 gave an $[\mathrm{M}+\mathrm{H}]^{+}$ion at $m / z$ 155.07034, corresponding to $\mathrm{C}_{8} \mathrm{H}_{10} \mathrm{O}_{3}$, and was tentatively identified as 3,4-dimethoxyphenol. Compound 27 was deduced as paeonolide based on the deprotonated ion at $m / z 299.1206$ and a fragment ion at $m / z 167.0707$.

Long chain fatty acid often provides ions by losses of $\mathrm{CO}_{2}, \mathrm{H}_{2} \mathrm{O}$, and $\left(\mathrm{CH}_{2}\right)_{\mathrm{n}}$ in MS spectrum. Compounds 64, 66, and 68 were accurately identified as hexadecanoic acid, 9-octadecenoic acid, and octadecanoic acid by comparing them with their reference standards. Compound 57 with $\mathrm{m} / \mathrm{z} 327.21889$ (calculated to be $\mathrm{C}_{18} \mathrm{H}_{32} \mathrm{O}_{5}$ ), compound 58 with $\mathrm{m} / \mathrm{z} 329.23479$ (calculated to be $\mathrm{C}_{18} \mathrm{H}_{34} \mathrm{O}_{5}$ ), compound 59 with $\mathrm{m} / \mathrm{z} 287.22468$ (calculated to be $\mathrm{C}_{16} \mathrm{H}_{32} \mathrm{O}_{4}$ ), compound 60 with $\mathrm{m} / \mathrm{z} 293.21325$ (calculated to be $\mathrm{C}_{18} \mathrm{H}_{30} \mathrm{O}_{3}$ ), compound 61 with $\mathrm{m} / \mathrm{z} 295.22859$ (calculated to be $\mathrm{C}_{18} \mathrm{H}_{32} \mathrm{O}_{3}$ ), and compound 65 with $\mathrm{m} / \mathrm{z} 355.32323$ (calculated to be $\mathrm{C}_{22} \mathrm{H}_{44} \mathrm{O}_{3}$ ) were tentatively identified as malyngic acid, 9,12,13-trihydroxyoctadec-10-enoic acid, 3,12-dihydroxyhexadecanoic acid, 9-oxooctadeca-10,12-dienoic acid, 13-hydroxy-9,11-octadecadienoic acid, and 2-hydroxybehenic acid, respectively [34].

Compound 1 showed $[\mathrm{M}+\mathrm{H}]^{+}$and $[\mathrm{M}+\mathrm{Na}]^{+}$at $\mathrm{m} / \mathrm{z} 343.12331$ and 365.10508 , and gave $\left[\mathrm{M}+\mathrm{Na}-\mathrm{C}_{6} \mathrm{H}_{10} \mathrm{O}_{5}\right]^{+}$at $m / z 203.0519$, suggesting the presence of disaccharide structure. Leuine (2) and tryptophan (13) were two amino acids with typical fragmentation ions by the loss of $\mathrm{CO}_{2}$ and $\mathrm{NH}_{3}$, and further confirmed by comparison with their reference standards. Compounds 7, 18, and 19 were three iridoids, and precisely identified as morroniside, loganin, and geniposide when compared with their reference standards. Guanosine (6) and adenosine (8) were two nucleosides. Compound 8 was directly identified as adenosine by comparison with its reference standard. Compound 6 was tentatively identified with accurate molecular weight and fragment ions in both positive and negative modes. Compound $\mathbf{1 1}$ gave an $[\mathrm{M}-\mathrm{H}]^{-}$ion at $\mathrm{m} / \mathrm{z} 218.1036$ and was tentatively identified as $\mathrm{N}$-(tert-Butoxycarbonyl)threonine. Compounds 62 and 63 were both pentacyclic triterpenoids with $[\mathrm{M}-\mathrm{H}]^{-}$ions at $\mathrm{m} / \mathrm{z} 471.34891$ and 455.35374 , and were tentatively identified as hederagenin and oleanolic acid, respectively [33]. Compound 67 gave an $[\mathrm{M}-\mathrm{H}]^{-}$ion at $\mathrm{m} / \mathrm{z} 399.32889$, calculated to be $\mathrm{C}_{27} \mathrm{H}_{44} \mathrm{O}_{2}$, and was inferred as dehydrotocopherol.

It can be shown that the flavonoid and phenolic contents in P. suffruticosa flower changes significantly during the flowering development stage (Figure 5). In this study, all compounds were detectable both in BEE and PEE. $p$-Hydroxybenzoic acid (15) could not be detected in FEE, and geniposide (19) and benzoylpaeoniflorin (54) could not be detected in the SEE. On the basis of the peak intensities in negative mode, there were 24 compounds with 10 -fold intensity change among the four extracts, including 8 terpenoids (morroniside (7), mudanoside A (12), mudanpioside E (23), galloyloxypaeoniflorin (30), mudanploside $H$ (42), mudanpioside $C$ (49), benzoyloxypaeoniflorin (51), and benzoylpaeoniflorin (54)), 10 flavonoids (eriodictyol-7-O-glucoside (22), quercetin-O-di-glucoside or isomer (26, 33), kaempferol-3,7-di-O-glucoside (29), patuletin-3,5-di-O-glucoside (32), quercetin-di-O-glucoside or isomer (33), 6,3'-dimethoxyquercetin-di-O-glucoside (37), monoxerutin (38), isorhamnetin-3-O-glucoside (44), apigenin (55), and chrysoeriol (56)), 4 phenols (gentisic acid-5-O-glucoside (14), $p$-hydroxybenzoic acid (15), 3,4-dimethoxyphenol (25), and paeonolide (27)), and 2 fatty acids (9,12,13-trihydroxyoctadec-10-enoic acid (58) and 3,12-dihydroxyhexadecanoic acid (59)). Considering the distribution of these largest abundant compounds, there were 4 compounds (7, 12, 14, and 26), one compound (56), 9 compounds (22, 25, 27, 29, 42, 49, 51, 54, and 55), and 10 compounds $(\mathbf{1 5}, \mathbf{2 3}, \mathbf{3 0}, \mathbf{3 2}, \mathbf{3 3}, \mathbf{3 7}, \mathbf{3 8}, \mathbf{4 4}, \mathbf{5 8}$, and 59) in BEE, FEE, PEE, and SEE, respectively. Obvious variation was easily found in the four extracts from the different flowering stages. The harvest stage was of the highest importance for the application of flowers, which affects chemical composition, nutritional value, and bioactivity. Flower harvesting at the correct stage could significantly increase quality, and even reduce the difficulty of product development. 


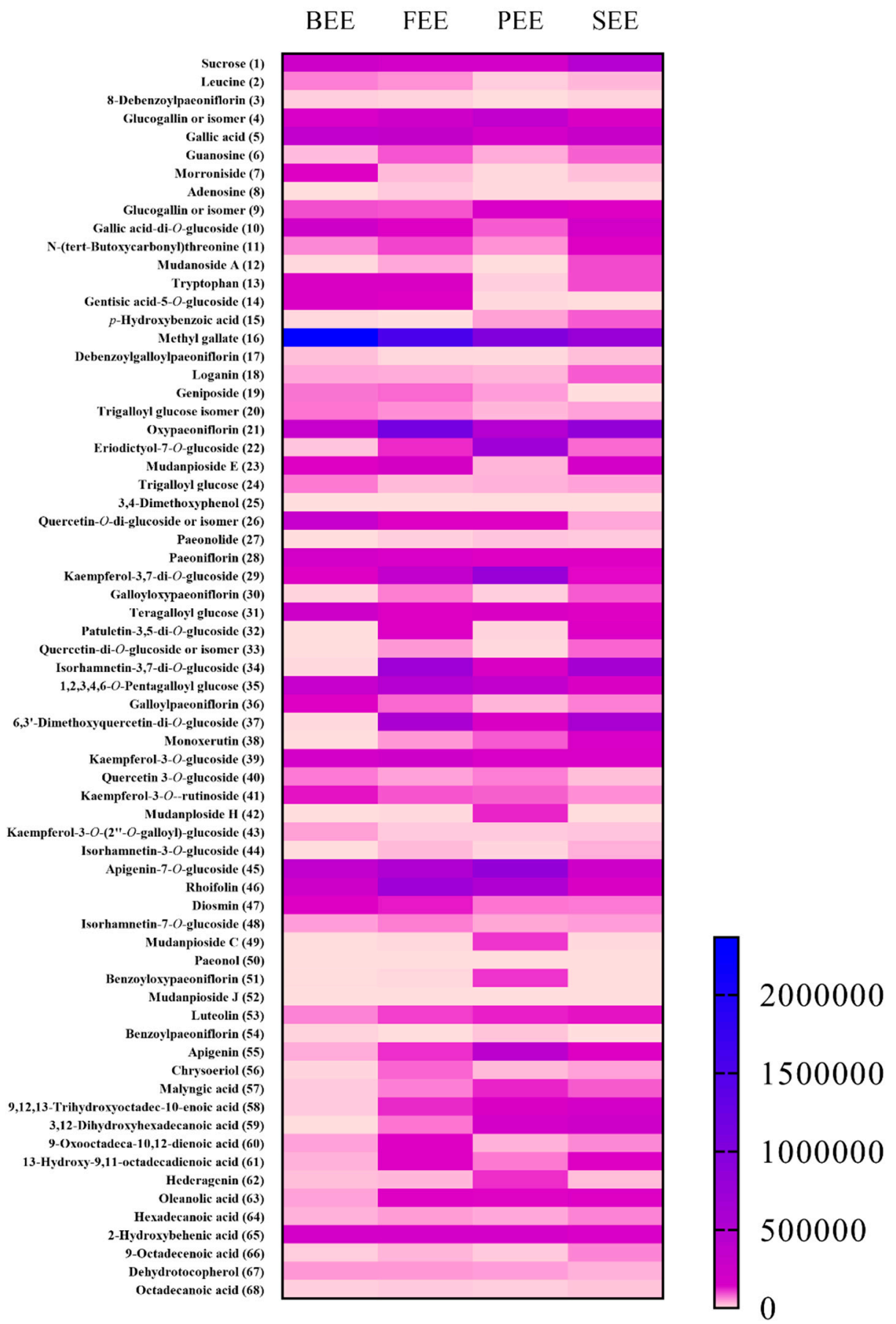

Figure 5. The peak intensities of the ethanolic extracts of Paeonia suffruticosa flowers. The peak intensities of the related compound in bud ethanolic extract (BEE), flower ethanolic extract (FEE), petal ethanolic extract (PEE), and stamen ethanolic extract (SEE) were obtained in negative mode. The numbered compounds were consistent with that in Table 2. 


\subsection{Determination of Phytochemicals in Ethanolic Extracts of P. suffruticosa Flowers}

In this study, though there were 68 compounds found by UFLC-Q-TOF-MS analysis, it was difficult to quantify all the 68 compounds by HPLC-DAD analysis due to the trace contents in the extracts, no/weak UV absorption, and no available standards commercially. Moreover, phenols, monoterpenoids, and flavonoids had multiple bioactivities, and they were predominant constituents in P. suffruticosa flowers. The method developed for the simultaneous determination of 3 phenols, 3 monoterpenoids, 2 flavonoids was validated by HPLC-DAD (Table 3). Gallic acid (5), 1,2,3,4,6-O-pentagalloyl glucose (35), and paeonol (50) were determined in the four extracts (Table 4). In BEE, the content of 1,2,3,4,6-O-pentagalloyl glucose (35) was $197.20 \pm 6.24 \mathrm{mg} / \mathrm{g}$ ext., which was higher than that of gallic acid (5) (159.99 $\pm 5.06 \mathrm{mg} / \mathrm{g}$ ext.) and paeonol (50) $(1.68 \pm 0.05 \mathrm{mg} / \mathrm{g}$ ext.). Unexpectedly, the content of gallic acid (5) was higher than that of 1,2,3,4,6-O-pentagalloylglucose (35) and paeonol (50) in the other three extracts. Oxypaeoniflorin (21) (6.93 $\pm 0.17 \mathrm{mg} / \mathrm{g}$ ext.), paeoniflorin (28) $(16.19 \pm 0.40 \mathrm{mg} / \mathrm{g}$ ext.), and benzoylpaeoniflorin (54) $(0.48 \pm 0.01 \mathrm{mg} / \mathrm{g}$ ext.) were able to be determined in PEE. The content of paeoniflorin (28) $(19.61 \pm 0.38 \mathrm{mg} / \mathrm{g}$ ext.) was much higher than that oxypaeoniflorin (21) $(10.46 \pm 0.20 \mathrm{mg} / \mathrm{g}$ ext.) in FEE, but the content of paeoniflorin (28) $(10.84 \pm 0.49 \mathrm{mg} / \mathrm{g}$ ext.) was a little lower than that of oxypaeoniflorin (21) $(11.19 \pm 0.50 \mathrm{mg} / \mathrm{g}$ ext.) in SEE. Benzoylpaeoniflorin (54) was not determined in FEE and SEE. The contents of luteolin (53) and apigenin (55) in PEE were $1.23 \pm 0.03 \mathrm{mg} / \mathrm{g}$ ext. and $1.48 \pm 0.04 \mathrm{mg} / \mathrm{g}$ ext., respectively. The contents of luteolin (53) in BEE, FEE, and SEE were lower than $0.16 \mathrm{mg} / \mathrm{g}$ ext., approximately one eighth of that in PEE. These results indicated that gallic acid (5) and 1,2,3,4,6-O-pentagalloyl glucose (35) were predominant compounds in ethanolic extracts of $P$. suffruticosa flowers, especially BEE. 
Table 3. Method validation of three phenols, three monoterpenoids, and two flavonoids.

\begin{tabular}{|c|c|c|c|c|c|c|c|c|}
\hline Compounds & Regression Equation & $\begin{array}{l}\text { Correlation } \\
\text { Coefficient (r) }\end{array}$ & $\begin{array}{c}\text { Linear Range } \\
(\mu \mathrm{g} / \mathrm{mL})\end{array}$ & $\begin{array}{l}\text { LOD } \\
(\mu \mathrm{g} / \mathrm{mL})\end{array}$ & $\begin{array}{c}\mathrm{LOQ} \\
(\mu \mathrm{g} / \mathrm{mL})\end{array}$ & $\begin{array}{c}\text { Intraday } \\
\text { Precision } \\
(\mathrm{RSD} \%, \mathrm{n}=6)\end{array}$ & $\begin{array}{c}\text { Interday } \\
\text { Precision } \\
(\mathrm{RSD} \%, n=6)\end{array}$ & $\begin{array}{l}\text { Accuracy } \\
(\%, n=6)\end{array}$ \\
\hline Gallic acid (5) & $y=9579.15 x-281.13$ & 0.99938 & $1.61-807.0$ & 0.48 & 1.61 & 1.77 & 2.60 & $97.05 \pm 4.64$ \\
\hline Oxypaeoniflorin (21) & $y=17106.22 x-36.29$ & 0.99952 & $1.44-72.00$ & 0.43 & 1.44 & 1.96 & 5.42 & $97.79 \pm 4.90$ \\
\hline Paeoniflorin (28) & $y=2380.45 x-11.64$ & 0.99987 & $0.98-246.0$ & 0.29 & 0.98 & 1.67 & 3.24 & $98.02 \pm 4.01$ \\
\hline $\begin{array}{l}\text { 1,2,3,4,6-O-Pentagalloyl } \\
\text { glucose (35) }\end{array}$ & $y=10624.06 x+58.48$ & 0.99957 & $1.06-532.0$ & 0.32 & 1.06 & 2.57 & 4.22 & $96.86 \pm 2.27$ \\
\hline Luteolin (53) & $y=20195.32 x-2.47$ & 0.99999 & $0.76-19.00$ & 0.23 & 0.76 & 1.19 & 3.93 & $99.14 \pm 3.96$ \\
\hline Apigenin (55) & $\mathrm{y}=17107.34 \mathrm{x}+12.70$ & 0.99987 & $1.72-43.00$ & 0.52 & 1.72 & 1.72 & 2.39 & $101.5 \pm 3.17$ \\
\hline Benzoylpaeoniflorin (54) & $y=2765.39 x-0.54$ & 0.99999 & $1.56-39.00$ & 0.47 & 1.56 & 1.70 & 3.50 & $101.8 \pm 5.17$ \\
\hline Paeonol (50) & $y=17767.49 x-3.55$ & 0.99978 & $1.96-49.00$ & 0.59 & 1.96 & 4.39 & 3.63 & $97.74 \pm 1.58$ \\
\hline
\end{tabular}

Table 4. Contents of three phenols, three monoterpenoids, and two flavonoids in the bud, flower, petal, and stamen ethanolic extracts of Paeonia suffruticosa flowers, as determined using HPLC-DAD analysis.

\begin{tabular}{|c|c|c|c|c|}
\hline Compounds & $\begin{array}{c}\text { BEE } \\
\text { (mg/g ext.) }\end{array}$ & $\begin{array}{c}\text { FEE } \\
\text { (mg/g ext.) }\end{array}$ & $\begin{array}{c}\text { PEE } \\
\text { (mg/g ext.) }\end{array}$ & $\begin{array}{c}\text { SEE } \\
\text { (mg/g ext.) }\end{array}$ \\
\hline Gallic acid (5) & $159.99 \pm 5.06$ & $46.98 \pm 0.92$ & $32.31 \pm 0.80$ & $40.39 \pm 1.82$ \\
\hline Oxypaeoniflorin (21) & nd & $10.46 \pm 0.20$ & $6.93 \pm 0.17$ & $11.19 \pm 0.50$ \\
\hline Paeoniflorin (28) & $1.76 \pm 0.06$ & $19.61 \pm 0.38$ & $16.19 \pm 0.40$ & $10.84 \pm 0.49$ \\
\hline $1,2,3,4,6$-O-Pentagalloyl glucose (35) & $197.20 \pm 6.24$ & $38.72 \pm 0.76$ & $26.25 \pm 0.65$ & $21.44 \pm 0.97$ \\
\hline Luteolin (53) & $0.14 \pm 0.004$ & $0.16 \pm 0.003$ & $1.23 \pm 0.03$ & $0.14 \pm 0.01$ \\
\hline Apigenin (55) & nd & nd & $1.48 \pm 0.04$ & nd \\
\hline Benzoylpaeoniflorin (54) & $1.30 \pm 0.04$ & nd & $0.48 \pm 0.01$ & nd \\
\hline Paeonol (50) & $1.68 \pm 0.05$ & $1.12 \pm 0.02$ & $2.60 \pm 0.06$ & $0.36 \pm 0.02$ \\
\hline
\end{tabular}

BEE: bud ethanolic extract; FEE: flower ethanolic extract; PEE: petal ethanolic extract; SEE: stamen ethanolic extract. nd: not detectable. Data were expressed as mean \pm SD $(n=3)$. 


\subsection{Pearson's Correlation Analysis between Phytochemicals and Bioactivities}

Pearson's correlation analysis has been used for the better understanding of the relationship between the phytochemicals and their bioactivities [35]. The correlation coefficient (r) of a single ingredient to each bioactivity is shown in Figure 6.

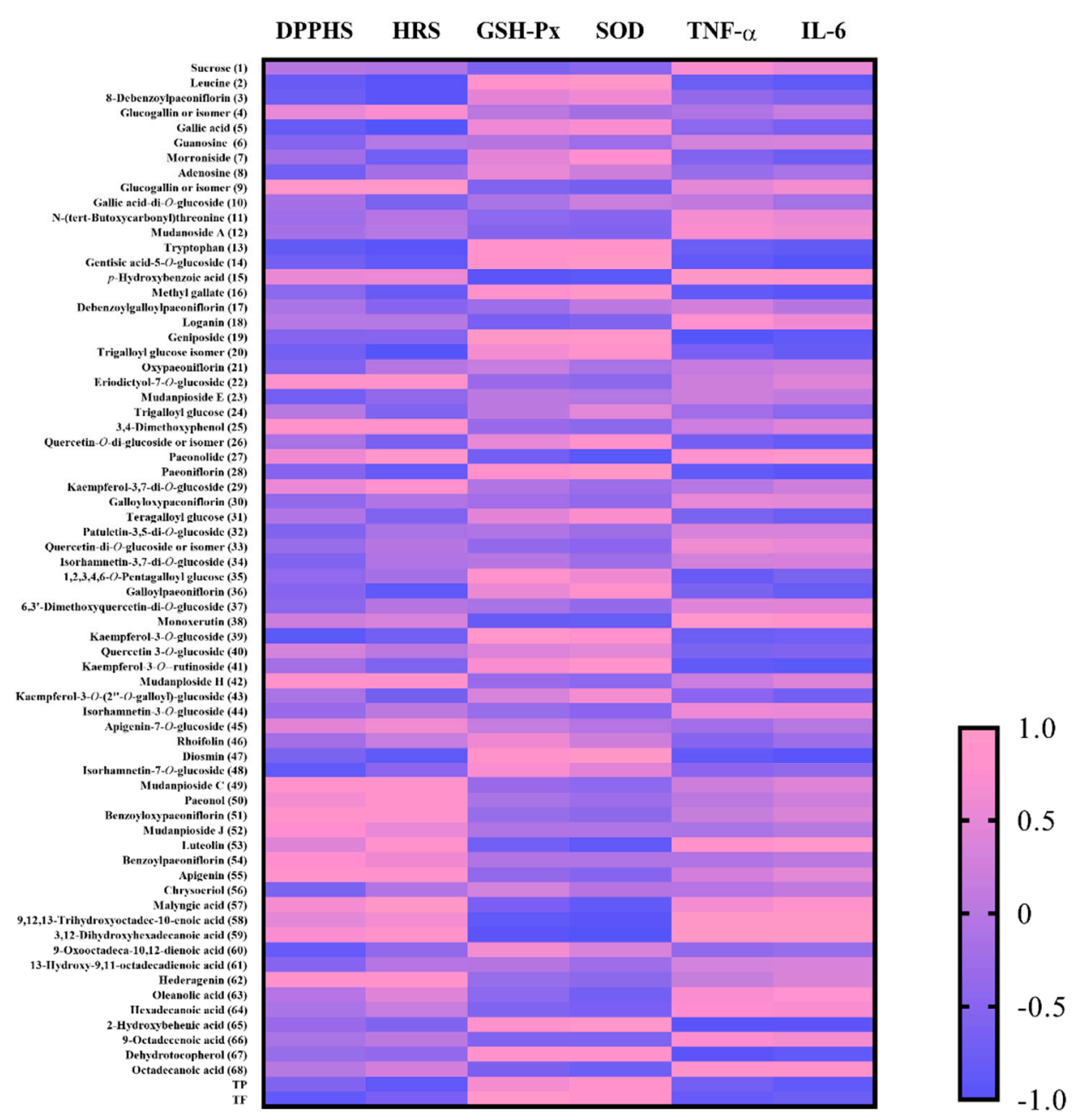

Figure 6. Correlation analysis between phytochemicals and bioactivities. The numbered compounds were consistent with that in Table 2. DPPHS: DPPH scavenging; HRS: hydroxyl radical scavenging.

Total phenolic and total flavonoid contents had a high negative correlation with DPPH and hydroxyl radical scavenging. Total phenolic content had a higher correlation with hydroxyl radical scavenging $(\mathrm{r}=-0.913)$ rather than DPPH scavenging $(\mathrm{r}=-0.549)$. By contrast, total flavonoid content had a higher correlation with DPPH scavenging $(\mathrm{r}=-0.862)$. Total phenolic and total flavonoid contents had a positive correlation with the activities of GSH-Px $\left(\mathrm{r}_{\mathrm{TPC}}=0.648 ; \mathrm{r}_{\mathrm{TFC}}=0.960, p<0.05\right)$ and $\operatorname{SOD}\left(\mathrm{r}_{\mathrm{TPC}}=0.885 ; \mathrm{r}_{\mathrm{TFC}}=0.811\right)$, and a negative correlation with the contents of TNF- $\alpha\left(\mathrm{r}_{\mathrm{TPC}}=-0.712\right.$; $\left.\mathrm{r}_{\mathrm{TFC}}=-0.847\right)$ and IL-6 $\left(\mathrm{r}_{\mathrm{TPC}}=-0.880 ; \mathrm{r}_{\mathrm{TFC}}=-0.783\right)$.

The correlation of phytochemicals and the antioxidant activity were further investigated. DPPH scavenging had no significant correlation with any compound. Hydroxyl radical scavenging had a significantly negative correlation with leucine (2), 8-debenzoylpaeoniflorin (3), gallic acid (5), tryptophan (13) and trigalloyl glucose isomer (20), and a significantly positive correlation with glucogallin or isomer (9) and malyngic acid (57). The activity of GSH-Px had a significantly positive correlation with geniposide (19) and a significantly negative correlation with $p$-hydroxybenzoic acid (15) and 3,12-dihydroxyhexadecanoic acid (59). The activity of SOD had a significantly positive correlation 
with gentisic acid-5-O-glucoside (14), methyl gallate (16), paeoniflorin (28), and diosmin (47), and a negative correlation with 9,12,13-trihydroxyoctadec-10-enoic acid (58) and 3,12-dihydroxyhexadecanoic acid (59). Gallic acid (5) and its derivatives, such as trigalloyl glucose (20), are strong natural antioxidants and can scavenge free radicals [36,37]. It has been reported that administration of geniposide (19), paeoniflorin (28), and diosmin (47) can significantly increase the activities of free radical scavenging enzymes such as SOD and GSH-Px [38-40].

It was found that the compounds significantly correlated with the content of IL-6 were identical to those of compounds correlated with the activity of SOD, but their correlations were opposite. It has been reported that paeoniflorin (28) and diosmin (47), with their potential anti-inflammatory capabilities, could significantly down-regulate the mRNA expression levels of IL-6 [39,41]. The content of TNF- $\alpha$ had a significantly positive correlation with glucogallin or isomer (9), and had a significantly negative correlation with leucine (2), gallic acid (5) and tryptophan (13). Interestingly, gallic acid (5) can inhibit mast cell-derived inflammatory allergic reactions via pro-inflammatory cytokine expression [42].

Gallic acid (5), methyl gallate (16), geniposide (19), trigalloyl glucose (20), paeoniflorin (28), and diosmin (47) were the critical compounds to the antioxidant, anti-photoaging and anti-inflammatory activities of $P$. suffruticosa flowers according to the results of Pearson's correlation analysis. These compounds should be the biomarkers in the product development and the quality control of P. suffruticosa flowers.

\section{Conclusions}

This study showed that $P$. suffruticosa flowers have different antioxidant and anti-photoaging properties at different flowering stages. The phytochemicals were elucidated, and a significant difference was found in terms of abundance. Meanwhile, the results of chemometric analysis proved that the multiple ingredients in P. suffruticosa flowers contributed to their antioxidant and anti-photoaging activities. In order to have the excellent antioxidant and anti-photoaging activities and high levels of bioactive phytochemicals, the optimal time to harvest the P. suffruticosa flower is before the early flowering stage. Taken together, this study provides valuable evidence that the $P$. suffruticosa flower has a great potential to be developed as functional material in food and health related industries.

Author Contributions: J.H., X.Z. and M.L. conceived and designed the experiments; J.H., Y.D., X.L., Y.W., T.G. and M.L. performed the experiments; J.H., X.Z. and M. L. analyzed the data; J.H. and M.L. wrote the paper.

Funding: This research was funded by Science and Technology Program of Guangzhou (No. 201904010337), National Natural Science Foundation of China (Nos. 31670056 and 31870776) and Guangdong Key Laboratory of Marine Materia Medica (LMM2018-5).

Conflicts of Interest: The authors declare no conflict of interest.

\section{References}

1. Muzaffer, U.; Paul, V.I.; Prasad, N.R.; Karthikeyan, R.; Agilan, B. Protective effect of Juglans regia L. against ultraviolet $\mathrm{B}$ radiation induced inflammatory responses in human epidermal keratinocytes. Phytomedicine 2018, 42, 100-111. [CrossRef] [PubMed]

2. Chen, L.; Hu, J.Y.; Wang, S.Q. The role of antioxidants in photoprotection: A critical review. J. Am. Acad. Dermatol. 2012, 67, 1013-1024. [CrossRef] [PubMed]

3. Tiraravesit, N.; Yakaew, S.; Rukchay, R.; Luangbudnark, W.; Viennet, C.; Humbert, P.; Viyoch, J. Artocarpus altilis heartwood extract protects skin against UVB in vitro and in vivo. J. Ethnopharmacol. 2015, 175, 153-162. [CrossRef] [PubMed]

4. Divya, S.P.; Wang, X.; Pratheeshkumar, P.; Son, Y.O.; Roy, R.V.; Kim, D.; Dai, J.; Hitron, J.A.; Wang, L.; Asha, P.; et al. Blackberry extract inhibits UVB-induced oxidative damage and inflammation through MAP kinases and NF-KB signaling pathways in SKH-1 mice skin. Toxicol. Appl. Pharm. 2015, 284, 92-99. [CrossRef] [PubMed]

5. Pandel, R.; Poljšak, B.; Godic, A.; Dahmane, R. Skin photoaging and the role of antioxidants in its prevention. ISRN Dermatol. 2013, 2013, 930163. [CrossRef] [PubMed] 
6. Han, C.V.; Bhat, R. In vitro control of food-borne pathogenic bacteria by essential oils and solvent extracts of underutilized flower buds of Paeonia suffruticosa (andr.). Ind. Crop. Prod 2014, 54, 203-208. [CrossRef]

7. Zhu, S.; Shirakawa, A.; Shi, Y.; Yu, X.; Tamura, T.; Shibahara, N.; Yoshimatsu, K.; Komatsu, K. Impact of different post-harvest processing methods on the chemical compositions of peony root. J. Nat. Med. 2018, 72, 757-767. [CrossRef]

8. Wang, Z.; He, C.; Peng, Y.; Chen, F.; Xiao, P. Origins, phytochemistry, pharmacology, analytical methods and safety of Cortex Moutan (Paeonia suffruticosa Andrew): A systematic review. Molecules 2017, 22, 946. [CrossRef]

9. Chen, L.J.; Games, D.E.; Jones, J. Isolation and identification of four flavonoid constituents from the seeds of Oroxylum indicum by high-speed counter-current chromatography. J. Chromatogr. A 2003, 988, 95-105. [CrossRef]

10. Ogawa, K.; Nakamura, S.; Sugimoto, S.; Tsukioka, J.; Hinomaru, F.; Nakashima, S.; Matsumoto, T.; Ohta, T.; Fujimoto, K.; Yoshikawa, M.; et al. Constituents of flowers of Paeoniaceae plants, Paeonia suffruticosa and Paeonia lactiflora. Phytochem. Lett. 2015, 12, 98-104. [CrossRef]

11. Yuan, J.; Hao, L.J.; Wu, G.; Wang, S.; Duan, J.A.; Xie, G.Y.; Qin, M.J. Effects of drying methods on the phytochemicals contents and antioxidant properties of chrysanthemum flower heads harvested at two developmental stages. J. Funct. Foods 2015, 19, 786-795. [CrossRef]

12. Zeng, H.; Su, S.; Xiang, X.; Sha, X.; Zhu, Z.; Wang, Y.; Guo, S.; Yan, H.; Qian, D.; Duan, J. Comparative analysis of the major chemical constituents in Salvia miltiorrhiza roots, stems, leaves and flowers during different growth periods by UPLC-TQ-MS/MS and HPLC-ELSD methods. Molecules 2017, 22, 771. [CrossRef] [PubMed]

13. He, J.Y.; Zhang, Y.H.; Ma, N.; Zhang, X.L.; Liu, M.H.; Fu, W.M. Comparative analysis of multiple ingredients in Rosa roxburghii and $R$. sterilis fruits and their antioxidant activities. J. Funct. Foods 2016, 27, $29-41$. [CrossRef]

14. Liu, M.H.; Ko, C.H.; Ma, N.; Tan, P.W.; Fu, W.M.; He, J.Y. Chemical profiles, antioxidant and anti-obesity effects of extract of Bambusa textilis McClure leaves. J. Funct. Foods 2016, 22, 533-546. [CrossRef]

15. Hassan, S.; Hussein, A.J.; Saeed, A.K. Role of green tea in reducing epidermal thickness upon ultraviolet light-B injury in BALB/c mice. Adv. Biol. 2015, 2015. [CrossRef]

16. Alu'datt, M.H.; Rababah, T.; Alhamad, M.N.; Al-Mahasneh, M.A.; Ereifej, K.; Al-Karaki, G.; Al-Duais, M.; Andrade, J.E.; Tranchant, C.C.; Kubow, S.; et al. Profiles of free and bound phenolics extracted from Citrus fruits and their roles in biological systems: Content, and antioxidant, anti-diabetic and anti-hypertensive properties. Food Funct. 2017, 8, 3187-3197. [CrossRef] [PubMed]

17. Lesjak, M.; Beara, I.; Simin, N.; Pintać, D.; Majkić, T.; Bekvalac, K.; Orčić, D.; Mimica-Dukić, N. Antioxidant and anti-inflammatory activities of quercetin and its derivatives. J. Funct. Foods 2018, 40, 68-75. [CrossRef]

18. Interdonato, R.; Rosa, M.; Nieva, C.B.; González, J.A.; Hilal, M.; Prado, F.E. Effects of low UV-B doses on the accumulation of UV-B absorbing compounds and total phenolics and carbohydrate metabolism in the peel of harvested lemons. Environ. Exp. Bot. 2011, 70, 204-211. [CrossRef]

19. Chen, G.L.; Chen, S.G.; Xie, Y.Q.; Chen, F.; Zhao, Y.Y.; Luo, C.X.; Gao, Y.Q. Total phenolic, flavonoid and antioxidant activity of 23 edible flowers subjected to in vitro digestion. J. Funct. Foods 2015, 17, $243-259$. [CrossRef]

20. Lee, H.J.; Im, A.R.; Kim, S.M.; Kang, H.S.; Lee, J.D.; Chae, S. The flavonoid hesperidin exerts anti-photoaging effect by downregulating matrix metalloproteinase (MMP)-9 expression via mitogen activated protein kinase (MAPK)-dependent signaling pathways. Bmc Complement. Altern. Med. 2018, 18, 39. [CrossRef]

21. Huang, C.Y.; Lin, Y.T.; Kuo, H.C.; Chiou, W.F.; Lee, M.H. Compounds isolated from Eriobotrya deflexa leaves protect against ultraviolet radiation B-induced photoaging in human fibroblasts. J. Photochem. Photobiol. B 2017, 175, 244-253. [CrossRef] [PubMed]

22. Lephart, E.D. Skin aging and oxidative stress: Equol's anti-aging effects via biochemical and molecular mechanisms. Ageing Res. Rev. 2016, 31, 36-54. [CrossRef] [PubMed]

23. Masaki, H. Role of antioxidants in the skin: Anti-aging effects. J. Dermatol. Sci. 2010, 58, 85-90. [CrossRef] [PubMed]

24. Nóbrega-Pereira, S.; Fernandez-Marcos, P.J.; Brioche, T.; Gomez-Cabrera, M.C.; Salvador-Pascual, A.; Flores, J.M.; Viña, J.; Serrano, M. G6PD protects from oxidative damage and improves healthspan in mice. Nat. Commun. 2016, 7, 10894. 
25. Wang, X.F.; Huang, Y.F.; Wang, L.; Xu, L.Q.; Yu, X.T.; Liu, Y.H.; Li, C.L.; Zhan, J.Y.; Su, Z.R.; Chen, J.N.; et al. Photo-protective activity of pogostone against UV-induced skin premature aging in mice. Exp. Gerontol. 2016, 77, 76-86. [CrossRef] [PubMed]

26. Martinez, R.M.; Fattori, V.; Saito, P.; Melo, C.B.P.S.; Borghi, M.; Pinto, I.C.; Bussmann, A.J.C.; Baracat, M.M.; Georgetti, S.R.; Verri, W.A., Jr.; et al. Lipoxin A4 inhibits UV radiation-induced skin inflammation and oxidative stress in mice. J. Dermatol. Sci. 2018, 91, 164-174. [CrossRef] [PubMed]

27. He, J.; Lu, X.; Wei, T.; Dong, Y.; Cai, Z.; Tang, L.; Liu, M. Asperuloside and asperulosidic acid exert an anti-Inflammatory effect via suppression of the NF- $\mathrm{BB}$ and MAPK signaling pathways in LPS-induced RAW 264.7 macrophages. Int. J. Mol. Sci. 2018, 19, 2027. [CrossRef] [PubMed]

28. Hsu, F.L.; Lai, C.W.; Cheng, J.T. Antihyperglycemic effects of paeoniflorin and 8-debenzoylpaeoniflorin, glucosides from the root of Paeonia lactiflora. Planta Med. 1997, 63, 323-325. [CrossRef] [PubMed]

29. Xu, S.J.; Yang, L.; Zeng, X.; Zhang, M.; Wang, Z.T. Characterization of compounds in the Chinese herbal drug Mu-Dan-Pi by liquid chromatography coupled to electrospray ionization mass spectrometry. Rapid Commun. Mass Spectrom. 2006, 20, 3275-3288. [CrossRef] [PubMed]

30. Zhao, W.; Geng, Y.; Cui, L.; Duan, W.; Wang, X.; Yan, H. Flavonoids from flowers of Paeonia suffruticosa Andr. Mod. Chin. Med. 2016, 18, 303-306.

31. Akimoto, N.; Ara, T.; Nakajima, D.; Suda, K.; Ikeda, C.; Takahashi, S.; Muneto, R.; Yamada, M.; Suzuki, H.; Shibata, D.; et al. Flavonoidsearch: A system for comprehensive flavonoid annotation by mass spectrometry. Sci. Rep. 2017, 7, 1243. [CrossRef] [PubMed]

32. Du, H.; Wu, J.; Ji, K.X.; Zeng, Q.Y.; Wang, L.S. Methylation mediated by an anthocyanin, O-methyltransferase, is involved in purple flower coloration in Paeonia. J. Exp. Bot. 2015, 66, 6563. [CrossRef] [PubMed]

33. Li, J.H.; Zeng, R.; Qu, Y.; Huang, L.F. Rapid identification on chemical constituents in roots of Paeonia delavayi var. Lutea by UPLC-Q-TOF-MSE combined with UNIFI informatics platform. Chin. Tradit. Herb. Drugs 2017, $48,1529-1536$.

34. Yu, S.; Du, S.; Yuan, J.; Hu, Y. Fatty acid profile in the seeds and seed tissues of Paeonia, L. species as new oil plant resources. Sci. Rep. 2016, 6, 26944. [CrossRef] [PubMed]

35. Wang, L.; Luo, Y.; Wu, Y.; Wu, Z. Impact of fermentation degree on phenolic compositions and bioactivities during the fermentation of guava leaves with Monascus anka and Bacillus sp. J. Funct. Foods 2018, 41, 183-190. [CrossRef]

36. Asnaashari, M.; Farhoosh, R.; Sharif, A. Antioxidant activity of gallic acid and methyl gallate in triacylglycerols of Kilka fish oil and its oil-in-water emulsion. Food Chem. 2014, 159, 439-444. [CrossRef] [PubMed]

37. Ngoc, T.M.; Hung, T.M.; Thuong, P.T.; Kim, J.C.; Min, B.S. Antioxidative activities of galloyl glucopyranosides from the stem-bark of Juglans mandshurica. Biosci. Biotechnol. Biochem. 2008, 72, 2158-2163. [CrossRef]

38. Chen, P.; Chen, Y.; Wang, Y.; Cai, S.; Deng, L.; Liu, J.; Zhang, H. Comparative evaluation of hepatoprotective activities of geniposide, crocins and crocetin by $\mathrm{CCl}_{4}$-induced liver injury in mice. Biomol. Ther. 2016, $24,156$. [CrossRef]

39. Zhang, M.H.; Feng, L.; Zhu, M.M.; Gu, J.F.; Wu, C.; Jia, X.B. Antioxidative and anti-inflammatory activities of paeoniflorin and oxypaeoniflora on AGEs-induced mesangial cell damage. Planta Med. 2013, 79, 1319-1323. [CrossRef]

40. Senthamizhselvan, O.; Manivannan, J.; Silambarasan, T.; Raja, B. Diosmin pretreatment improves cardiac function and suppresses oxidative stress in rat heart after ischemia/reperfusion. Eur. J. Pharmacol. 2014, 736, 131-137. [CrossRef]

41. Imam, F.; Al-Harbi, N.O.; Al-Harbi, M.M.; Ansari, M.A.; Zoheir, K.M.; Iqbal, M.; Anwer, M.K.; Al-Hoshani, A.R.; Attia, S.M.; Ahmad, S.F. Diosmin downregulates the expression of T cell receptors, pro-inflammatory cytokines and NF- $\mathrm{B}$ activation against LPS-induced acute lung injury in mice. Pharmacol. Res. 2015, 102, 1-11. [CrossRef] [PubMed]

42. Kim, S.H.; Jun, C.D.; Suk, K.; Choi, B.J.; Lim, H.; Park, S.; Lee, S.H.; Shin, H.Y.; Kim, D.K.; Shin, T.Y. Gallic acid inhibits histamine release and pro-inflammatory cytokine production in mast cells. Toxicol. Sci. 2005, 91, 123-131. [CrossRef] [PubMed]

(C) 2019 by the authors. Licensee MDPI, Basel, Switzerland. This article is an open access article distributed under the terms and conditions of the Creative Commons Attribution (CC BY) license (http://creativecommons.org/licenses/by/4.0/). 